\title{
The Development of Graphene/Silica Hybrid Composites: A Review for Their Applications and Challenges
}

\author{
Murni Handayani ${ }^{1, *}$, Nurin Nafi'ah ${ }^{2}$, Adityo Nugroho ${ }^{2}$, Amaliya Rasyida ${ }^{2}$, Agus Budi Prasetyo ${ }^{1}$, Eni Febriana ${ }^{1}$, \\ Eko Sulistiyono ${ }^{1}$ and Florentinus Firdiyono ${ }^{1}$ \\ 1 Research Center for Metallurgy and Materials-National Research and Innovation Agency (BRIN), \\ Building 470, PUSPIPTEK Area, Tangerang Selatan 15314, Indonesia; agus080@lipi.go.id (A.B.P.); \\ enif001@lipi.go.id (E.F.); ekos001@lipi.go.id (E.S.); flor001@lipi.go.id (F.F.) \\ 2 Department of Materials and Metallurgical Engineering, Institut Teknologi Sepuluh Nopember, \\ Surabaya 60111, Indonesia; nurin.18025@mhs.its.ac.id (N.N.); adityonugroho.18025@mhs.its.ac.id (A.N.); \\ amaliya@mat-eng.its.ac.id (A.R.) \\ * Correspondence: murni.handayani@lipi.go.id or murni.handayani@brin.go.id
}

Citation: Handayani, M.; Nafi'ah, N.; Nugroho, A.; Rasyida, A.; Prasetyo, A.B.; Febriana, E.; Sulistiyono, E.; Firdiyono, F. The Development of Graphene/Silica Hybrid Composites: A Review for Their Applications and Challenges. Crystals 2021, 11, 1337. https://doi.org/10.3390/ cryst11111337

Academic Editor: Walid M. Daoush

Received: 20 September 2021

Accepted: 26 October 2021

Published: 1 November 2021

Publisher's Note: MDPI stays neutral with regard to jurisdictional claims in published maps and institutional affiliations.

Copyright: (c) 2021 by the authors. Licensee MDPI, Basel, Switzerland. This article is an open access article distributed under the terms and conditions of the Creative Commons Attribution (CC BY) license (https:// creativecommons.org/licenses/by/ $4.0 /)$.

\begin{abstract}
Graphene and silica are two materials that have wide uses and applications because of their unique properties. Graphene/silica hybrid composite, which is a combination of the two, has the good properties of a combination of graphene and silica while reducing the detrimental properties of both, so that it has promising future prospects in various fields. It is very important to design a synthesis method for graphene/silica composite hybrid materials to adapt to its practical application. In this review, the synthesis strategies of graphene, silica, and hybrid graphene/silica composites such as hydrothermal, sol-gel, hydrolysis, and encapsulation methods along with their results are studied. The application of this composite is also discussed, which includes applications such as adsorbents, energy storage, biomedical fields, and catalysts. Furthermore, future research challenges and futures need to be developed so that hybrid graphene/silica composites can be obtained with promising new application prospects.
\end{abstract}

Keywords: graphene; silica; hybrid composites; nanocomposites; adsorbents; energy storages; biomedical fields; catalysts

\section{Introductions}

In the period 1982-1983, the major concept re-direction of the sol-gel process to create heterogeneous material was explained by Roy, Komarneni, and colleagues. During the process, the term 'nanocomposite' was often used [1]. Nanocomposite, solid phase material, has at least one dimension in the nanometre range on amorphous, semicrystalline, or crystalline or combinations thereof. Composition of nanocomposites are design based on multifunctional properties that refer to the inorganic or organic, or both $[1,2]$.

To a great extent in the last two decades, the progression of many aspects built by nanocomposite has been developed. Nanocomposite properties are influenced by the structures. Therefore, the need for understanding and practicing material behavior across length scales from the atomic to the macroscopic scale is important for scientists and engineers. Commonly, their reinforced material is divided into particles, layered materials, and fibrous materials [2].

Similarly, nanocomposites are also divided by their matrix. There are polymer matrix nanocomposites, ceramic matrix nanocomposites, and metal matrix nanocomposites [3]. Extraordinary properties were obtained by combining various materials as previously mentioned. such as its based composition, reinforcement, or matrix on the design material process by the scientist and engineer. Essentially, a variety of applications of nanocomposites is achieved by versatile properties that could be enhanced from their manufacturing [4]. Recently, nanocomposites have widely been applied in environmental remedies, energy, 
medicine, sunscreens, biomaterials, etc. Nanocomposites are becoming an attractive field of materials which provide novel performance due to their remarkable properties [5]. Currently, nanocomposites are widely used in industry to replace the use of conventional fillers because most of the nanoscale fillers are able to improve the mechanical and thermal properties of nanocomposites [6].

Graphene, a semimetal thin material, is a single layer carbon atom with 2 dimensional sheets in a densely packed honeycomb lattice structure [5]. Since its discovery, it has continuously been making an impact on future material development, increasing research into advance synthesis methods from year to year, in order to confront industrial challenges from many angles, such as automotive, green energy, electronics, biomedical, catalyst and others [7]. The graphene-copper (II) phthalocyanine ( $\mathrm{CuPc}$ ) hybrid material has been used as an electrocatalyst for the electrochemical reduction of $\mathrm{CO}_{2}$ [8]. Meanwhile, reduced $\mathrm{Nickel/graphene} \mathrm{oxide} \mathrm{nanoparticles} \mathrm{were} \mathrm{applied} \mathrm{as} \mathrm{a} \mathrm{catalyst} \mathrm{to} \mathrm{convert} \mathrm{CO}_{2}$ to $\mathrm{CH}_{4}$ by showing good activity in $\mathrm{CO}_{2}$ methanation processes [9].

Starting from the academic field to isolated graphite in 2004, existing theoretical possibility in preparing tiny sheets of graphene, within 10 years becoming a high prospect project in growing economical and innovative research for society, aiming dynamics field and multitude of actors on commercial [7]. Graphene discovery was a sign of the new era for researchers and the material physics community to collect the "gold" from the "hidden gold mine". [10].

With numerous functions and a high chance of becoming a future material, graphene has been supported by its great properties. It has a large surface area $\left(2630 \mathrm{~m}^{2}\right)$, high electrical conductivity $\left(10^{6} \mathrm{~S} \mathrm{~cm}^{-1}\right)$, high thermal conductivity $\left(5000 \mathrm{~W} \mathrm{~m}^{-1} \mathrm{~K}^{-1}\right)$, high mechanical strength $\left(\sim 40 \mathrm{Nm}^{-1}\right)$, great optical transmittance $(\sim 97.7 \%)$, high modulus of elasticity (1 TPa), and high electron intrinsic mobility $\left(250000 \mathrm{~cm}^{2} \mathrm{~V}^{-1} \mathrm{~s}^{-1}\right)$ [11-13]. Primarily, due to the potential value of graphene, analysis of this material is focused on its properties such as electrical, physical, mechanical, and optical [12]. For example, recognizing that properties needed for several characterization methods are likely optical microscopy, transmission electron microscopy (TEM), atomic force microscopy (AFM), angle-resolved photoemission spectroscopy (ARPES), Raman scattering and Rayleigh scattering [14]. In the case of graphene attractive properties, various applications have been listed including high-end composite materials, field effect transistors, electromechanical systems, strain sensors, electronics, supercapacitors, hydrogen storage and solar cells [13].

Silica is an inexhaustible resource on earth [15] that can be found both from natural resources [16] and inorganic compounds [17]. Agricultural waste such as rice husks, rice hulls, bagasse ash, semi-burned rice straw ash [18], bentonite, quartz sand, and diatomaceous earth [15] are the natural resources containing high silica. Meanwhile, silica obtained from inorganic compounds, namely TEOS (Tetraethyl Orthosilicate) [18], SSS (Sodium Silicate Solution), and TMOS (Tetramethyl Orthosilicate) can be synthesized from silane [17]. In recent years, the synthesis of silica from natural materials has been growing with various advantages. The natural evolution of plants over the years has been able to develop silica layers and produce highly reactive silica by a simple process [15].

Silica has wide applications in various fields including drug delivery systems, catalysis, biomedical, imaging, chromatography, sensors and as a filler composite material [18]. Porous silica ceramics as candidates for high temperature dielectrics and thermal shields with their dielectric and thermal properties as well as low density used in aerospace and engineering [19]. Naturally, silica has a tendency to produce the strength and hardness of ceramic materials [15]. In addition, silica aerogel is a promising material used in composite insulators with its porous, ultra-lightweight, and nanostructured properties. It also can be used as a material for water resistance, UV protection, fire resistance, and has excellent acoustic barrier properties [20]. Silica gel with a high specific surface area and a gas adsorption capacity due to the presence of micro and mesopores is used as an adsorbent such as for removal of heavy metals from wastewater and the adsorption of volatile organic 
compounds [21]. In other fields of application, silica nanoparticles are used as superhydrophobic materials by changing their hydrophilic properties to hydrophobic ones [22].

Based on the several advantages possessed by graphene and silica, both can be integrated to produce better new properties. The synthesis of graphene silica hybrid composites will produce properties that integrate the two and can avoid performance degradation caused by agglomeration of graphene [23]. Stack agglomeration that occurs in the graphene preparation process will greatly reduce the specific surface area, thereby reducing the performance of graphene. The combination of graphene and silica can effectively reduce agglomeration and produce advanced functional materials [24]. This material has complementary advantages and considerable application prospects in many fields. Currently, graphene and silica $\left(\mathrm{G} / \mathrm{SiO}_{2}\right)$ hybrid composites are widely applied for electrodes, catalysts, hydrogen storage, batteries, displays, adsorbents, and sensors [23].

In this paper review, we report on the current focus on the development of graphenesilica hybrid composites and their applications in various fields. Furthermore, various synthesis methods for graphene, silica, and graphene-silica hybrid composites have been summarized according to sources. The functions and applications of graphene-silica hybrid composites in various fields are briefly discussed.

\section{Synthesis Methods}

\subsection{Synthesis Method of Silica}

Silica extraction from several sources with various methods aims to produce silica with a high purity and a high quality. Several researchers have conducted research to synthesize silica from its source with various methods and have focused on the environmental regulation of temperature and combustion time as well as chemical treatment so as to produce different structures and properties of silica amorphous to the crystalline phase [25].

\subsubsection{Sol-Gel Method}

Sol-gel is the most frequently used method in silica synthesis and is suitable for the manufacturing industry. The reaction in this method is controlled by one of the acidic or basic conditions. By using this method, a uniform silica particle in size, high purity, ease of control and scalability was achieved [22]. Abbas, et al. [20] conducted an experiment on extracting silica aerogel from rice husks using the sol-gel method for application in environmentally friendly, lightweight, and heat-resistant cement composites. It uses sodium hydroxide solution to form hydrogel, is immersed in ethanol to make an alcogel and surface modification to form a hydrophobic gel, and is then dried to produce silica aerogel. The result showed a dominant mesoporous structure and a high surface area of $760 \mathrm{~m}^{2} / \mathrm{g}$. The addition of silica aerogel to the cement composite can reduce the density from $2102 \mathrm{~kg} / \mathrm{m}^{3}$ to $1133 \mathrm{~kg} / \mathrm{m}^{3}$ and lowers the thermal conductivity from $1.76 \mathrm{~W} / \mathrm{mK}$ to $0.33 \mathrm{~W} / \mathrm{mK}$.

In the study by Ismail et al. [22], the extraction of silica nanoparticles from silica sand using is performed mechanically by grinding and the sol-gel method is used as a superhydrophobic material. To form a silica superhydrophobic, silica nanoparticles were mixed with stearic acid and ethanol. It was observed that the particle size increased with the increasing chain length of the alcohol. The particle size distribution was related to solvent polarity, which influenced the nucleation and growth of the silica particles. Methanol is the most polar alcohol solvent, which can increase the solubility of sodium silicate and therefore obtained a high concentration of very small silica nuclei. The superhydrophobic effect of silica nanoparticles can also be seen in their application, both as coatings and as mixed materials.

The sol-gel method was also used in the research of Sdiri et al. [21] to extract silica gel from siliceous sands. Silica sand was mixed with sodium carbonate to prepare sodium silicate, and hydrochloric acid was then added to obtain silica gel in micro and mesoporous pores with a high adsorption capacity. The silica content resulting from this method was $88.8-97.5 \%$. The porosity of the silica gel reaches $57 \%$ and the specific surface area exceeds 
$340 \mathrm{~m}^{2} /$ G. Silica gel obtained from this method was in micro and mesoporous pores with a high adsorption capacity, which has potential to be applied to adsorbents, such as heavy metal removal from wastewater and the adsorption of volatile organic compounds.

\subsubsection{Hydrothermal}

The hydrothermal method is one of the processes used to synthesize silica with a low cost and a simple technique in the preparation of nanomaterials [26]. The synthesis of amorphous silica nanowires from commercial silicate glass was carried out by Zhu Y et al. [26] using the one-step hydrothermal method. The hydrothermal process was carried out at a temperature of $170{ }^{\circ} \mathrm{C}$. The results showed that the silica in nanoscale was achieved in the form of an amorphous $\mathrm{SiO}_{2}$ nanowire with a diameter of $20-100 \mathrm{~nm}$ and a length of several tens of micrometers.

In a study by Ortiz et al. [27], MCM-41 mesoporous silica was synthesized by a hydrothermal method using sodium silicate $\left(\mathrm{Na}_{2} \mathrm{SiO}_{3}\right)$ as a source of silica, hexadecyltrimethylammonium bromide (CTAB) as a template agent, and ethyl acetate as a $\mathrm{pH}$ regulator. The synthesis was carried out at 80,90 , and $100^{\circ} \mathrm{C}$, resulting in an increase in temperature affecting the formation of MCM-41 silica negatively. Mesoporous silica MCM-41 is synthesized from these reaction conditions depicted in a well-ordered hexagonal array with spherical morphology and particle sizes of 200 to $500 \mathrm{~nm}$. MCM-41 mesoporous silica could have promising applications in catalysis, drug delivery systems and the adsorption of organic molecules owing to its high specific surface area.

\subsubsection{Leaching}

The two main steps in extracting silica, especially from natural resources, are combustion and chemical treatment. Dissolution of materials in acid can be used to remove organic compounds in materials before combustion [28]. A method of chemical treatment with hydrochloric acid or sulfuric acid was used to prepare ultrafine size silica, high reactivity and high purity. The purpose of acid pretreatment is to increase purity by removing impurities and gives the silica a high surface area during its deposition [25]. Eko, et al. [29] applied sulfuric acid for the leaching process of low-grade silica from quartz sand. The result depicted sulfuric acid as being very effective to remove impurities of aluminum and iron up to $42 \%$ and $85 \%$, respectively. The process using sulfuric acid could produce high purity silica with $96.44 \%$ purity.

In environmentally friendly chemical extraction methods, there are acid alkaline treatment and washing steps aimed at controlling the size and pores in the silica particles $[25,26]$. Febriana, et al. [30] has succeeded in synthesizing silica by a direct leaching method at atmospheric pressure. Precipitated silica content of $13.6 \%$ was obtained under optimum conditions at a temperature of $90{ }^{\circ} \mathrm{C}$ and a stirring speed of $800 \mathrm{rpm}$, with a sodium hydroxide solution of $7.5 \mathrm{M}$, which produced amorphous precipitate silica with a purity of $\pm 96 \%$. Azat, et al. [25] conducted an experiment to extract silica from rice husk. The leaching process used a hydrochloric acid solution and was calcined at $600^{\circ} \mathrm{C}$. The amorphous silica with a purity of $98.2-99.7 \%$ and a certain surface area of $120-980 \mathrm{~m}^{2} / \mathrm{G}$ was produced from this method.

Another study by Park et al. [28] demonstrating the process of extracting silica from rice husks uses a two-stage continuous process consisting of a friction ball attrition and an alkaline washing method. With the use of $\mathrm{NaOH}$, the silica yield becomes saturated, starting from $0.2 \mathrm{M}$ and a yield of $79 \%$. With the use of $\mathrm{KOH}$, silica yields a saturation starting from $0.5 \mathrm{M}$ with a yield of about $77 \%$. The optimum reaction conditions were a concentration of $0.2 \mathrm{M}$ at $80{ }^{\circ} \mathrm{C}$ for $3 \mathrm{~h}$, and a solid content of $6 \%(w / v)$. This extraction method produces amorphous silica with $98.5 \%$ purity. Synthesis of amorphous and crystalline silica from rice husk was also carried out by Zainal et al. [15] using chemical treatment with hydrochloric acid at a temperature of $60^{\circ} \mathrm{C}$. The combustion was carried out at a temperature of $700{ }^{\circ} \mathrm{C}$ and $1000{ }^{\circ} \mathrm{C}$ for $2 \mathrm{~h}$. From the experiment, it was found that 
amorphous silica is formed at $700{ }^{\circ} \mathrm{C}$ and crystalline silica is formed at $1000{ }^{\circ} \mathrm{C}$. Chemical treatment before combustion increased the silica content from $95.7 \%$ to $98.7 \%$.

\subsubsection{Pyrolysis}

Pyrolysis is one of the methods used to synthesize silica. Catalyst-assisted pyrolysis of polymeric precursors for nanostructures is a simple and easy controlling method. Moreover, its products are of a high purity. It can be applied in fabricating Si-based nanostructures by adjusting the composition of polymeric precursors, catalysts, and atmospheres [31]. In the study of Cho et al. [32], silica particles were synthesized by the flame spray pyrolysis (FSP) method from two precursors of tetraethylorthosilicate (TEOS) and silicate acid. When the concentration of TEOS is increased from 0.1 to $0.5 \mathrm{M}$, the specific surface area of silica powder is decreased from 285 to $81.4 \mathrm{~m}^{2} / \mathrm{g}$ and the average particle size is increased from 9.6 to $33.5 \mathrm{~nm}$.

Research conducted by Gao, et al. [31] nano-/submicron silica spheres were successfully synthesized by the pyrolysis method from amorphous polysilazane preceramic powder with $\mathrm{FeCl}_{2}$ catalyst. The perhydropolysilazane precursor was solidified by heating at $260{ }^{\circ} \mathrm{C}$ for $0.5 \mathrm{~h}$ in $\mathrm{N}_{2}$. The mixture of amorphous $\mathrm{SiCN}$ with $\mathrm{FeCl}_{2}$ was heated to $1250{ }^{\circ} \mathrm{C}$ and pyrolyzed there for $2 \mathrm{~h}$. This experiment resulted in an amorphous silica with a diameter of 600-800 $\mathrm{nm}$ and a smooth clean surface without any flaws.

A comparison of the result characteristic from several different synthesis methods can be seen in Table 1.

Table 1. Comparison of the result and method of silica synthesis.

\begin{tabular}{|c|c|c|c|c|c|c|}
\hline Paper & Source of Silica & Method & Purity (\%) & Particle Size (nm) & Product & Surface Area $\left(\mathrm{m}^{2} / \mathrm{g}\right)$ \\
\hline $\begin{array}{l}\text { Abbas, et al. } \\
(2019) \text { [20] }\end{array}$ & Rice husk & Sol-gel & - & - & Mesoporous & 760 \\
\hline $\begin{array}{l}\text { Ismail, et al. } \\
\text { (2021) [22] }\end{array}$ & Silica sand & Sol-gel & - & $170.3 \pm 14.3$ & Nanoparticle & - \\
\hline $\begin{array}{l}\text { Sdiri, et al. } \\
(2014)[21]\end{array}$ & Siliceous sand & Sol-gel & $88.8-97.5$ & - & $\begin{array}{l}\text { Micro and } \\
\text { mesoporous }\end{array}$ & 340 \\
\hline $\begin{array}{l}\text { Zhu Y, et al. } \\
\text { (2019) [26] }\end{array}$ & Silicate glass & Hydrothermal & - & 20-100 & $\begin{array}{l}\text { Amorphous } \\
\text { nanowires }\end{array}$ & - \\
\hline $\begin{array}{l}\text { Ortiz, et al. } \\
\text { (2013) [27] }\end{array}$ & Sodium silicate & Hydrothermal & - & $200-500$ & Mesoporous & 860-1028 \\
\hline $\begin{array}{l}\text { Azat, et al. } \\
\text { (2019) [25] }\end{array}$ & Rice husk & Leaching & $98.2-99.7$ & - & Amorphous & $120-980$ \\
\hline $\begin{array}{l}\text { Park, et al. } \\
(2021) \text { [28] }\end{array}$ & Rice husk & Leaching & 98,5 & - & Amorphous silica & 1973 \\
\hline $\begin{array}{l}\text { Zainal, et al. } \\
\text { (2019) [15] }\end{array}$ & Rice husk & Leaching & 98 & - & $\begin{array}{l}\text { Amorphous and } \\
\text { crystalline }\end{array}$ & - \\
\hline $\begin{array}{l}\text { Gao, et al. } \\
(2013)[31]\end{array}$ & $\begin{array}{l}\text { Polylazane } \\
\text { preceramic } \\
\text { powder }\end{array}$ & Pyrolysis & - & $600-800$ & $\begin{array}{l}\text { Nano-/submicron } \\
\text { spheres }\end{array}$ & - \\
\hline $\begin{array}{l}\text { Cho, et al. } \\
\text { (2009) [32] }\end{array}$ & $\begin{array}{l}\text { TEOS and silicate } \\
\text { acid }\end{array}$ & Pyrolysis & - & $9.6-33.5$ & Particle & 81,4 \\
\hline
\end{tabular}

\subsection{Synthesis Method of Graphene}

About two past decades, since its first mechanically exfoliation, graphene has been widely synthesized with many various methods and materials. Graphene synthesis can be divided into two different methods, there are: 'Bottom-up' and 'Top-down' [11,33]. The bottom-up method is by using another substrate as a field for planting the graphene by putting the carbon precursor vapor into them, or in other words, using a different source that contains carbon rather than graphite. Meanwhile, for top-down methods using mechanical or chemical steps to obtain one single layer graphene from the structure of the graphite and derivatives (graphite oxide and graphite fluoride), or crushing apart multiple layer graphite into a single graphene sheet $[11,34]$. The detailed explanation of synthesis graphene is described in the following sections. 


\subsubsection{Top-Down Approaches}

The Top-Down method processing raw material into final product that can be used to widely apply in industry. Starting from its first exfoliation in 2004, a thousand trials have been elevated to produce graphene from graphite. This method has several benefits compared with bottom-up methods, such as its potential to scale up, optimization of cost revenue, no need for substrate transfer, and its high productivity [35]. Therefore, the topdown method is mainly used on large-scale implementations. Some methods are discussed in the following segments.

\section{Exfoliation Method}

Basically, this method is the easiest and most widely used to synthesize graphite into graphene. An exfoliation method is divided into several types: mechanical exfoliation (scotch tape), chemical/electrochemical exfoliation, thermal exfoliation, and electrical exfoliation [35,36]. Mechanical exfoliation, also known as scotch tape, was developed by Geim and Novoselov in 2004 by using highly oriented pyrolytic graphite (HOPG) as a precursor and subjected it into oxygen plasma etching. As a result, $5 \mu \mathrm{m}$ deep mesas existed and then it pressed into a layer of photoresist to the baking process. To peel out flakes of graphite from the mesas, scotch tape was used. After that, the thin flakes obtained are deposited to acetone and framed on the surface of $\mathrm{Si} / \mathrm{SiO}_{2}$ wafer. SEM and optical microscopy were used to analyze the few-layer graphene (FLG) formed. From this, Geim and Novoselov gained few- and single-layer graphene flakes up to $10 \mu \mathrm{m}$ in size [5,37].

GICs, graphite intercalation compounds, were structured by graphite with atoms or molecules in compounds which were intercalated between the carbon layers. Mechanical and thermal exfoliation was served by this intercalation because of its characteristics. The increase in space between the layers weakened the interlayer interactions. The arrangement of the layer involved stacking from first stage GICs to the higher stage to complete formed monolayer platelets. Then, the expanded graphite (EG) could be produced from the higher stage GIC by exfoliating in rapid heating [36]. Graphene oxide (GO) could be formed from graphite oxide by using mechanical exfoliation (i.e., ultrasonication and stirring), since graphite oxide has natural hydrophilic and larger space interlayers along concentration $3 \mathrm{mg} / \mathrm{mL}$ [36].

Eswaraiah et al. (2011) implemented this method using focused solar radiation [38]. From a convex lens of $90 \mathrm{~mm}$ diameter, solar radiation is intensified and is directed to graphite oxide. It will increase the temperature of solar radiation by $150-200{ }^{\circ} \mathrm{C}$ from ambient temperature and a change in power from $60 \mathrm{~mW}$ to $2 \mathrm{~W}$. The color of graphite oxide is also changed from light brown to dark black due to the high intensity of radiation. Exfoliation happens at a low temperature $\left(150-200^{\circ} \mathrm{C}\right)$ because of the rapid heating rate $\left(>100^{\circ} \mathrm{C} \mathrm{s}^{-1}\right)$, then decomposition of the functional group occurs with the evolution of $\mathrm{CO}_{2}$. The synthesis result depicts most of the GO as being efficiently exfoliated to form separated, ultrathin, and transparent sheets. Moreover, TEM images show the wrinkled nature of the graphene sheets. The thickness of graphene sheets calculated by HRTEM lattice imaging came out to be $\sim 1 \mathrm{~nm}$. The average step heights measured between the surface of the sheets and the substrate were found to be $\sim 0.9$ to $1.4 \mathrm{~nm}$, proving them to be two atoms thick.

\section{Chemical Reduction of Graphene Oxide/Organic Treatment}

Chemical reduction triggered the exfoliated graphene oxide sheets to produce a balanced colloidal dispersion of graphene oxide (GO) [39]. Graphite oxide has hydrophilic characteristics in several solvents, including water, alcohol, etc. The same as graphite oxide, graphene oxide is suspended by sonication in solvents and acts as a precursor for graphene synthesis $[37,40]$. Purposing graphene formed by oxidizing graphite into graphene is one step ahead of producing a bulk graphene process [41]. Single- or multi-layer GO is created by the modification of Hummer's original method, and is adjusted in a thermal or chemical process [11,37]. 
Handayani et al. used sulphuric acid, sodium nitrite, and hydrogen peroxide potassium permanganate as chemical reagents in this method [42]. An exfoliation and intercalation process are performed by oxidizing graphite powder into graphene oxide and reducing it into graphene in polar aprotic solvents. Brownish graphene oxide from chemical treatment is the product and then sodium borohydride is added as a reducing agent to dispersing graphene oxide, turning the color black and homogenizing it. Abbas, et al. synthesized graphene oxide from Spent coffee beans via modified Hummer's method and reduced graphene oxide to form graphene using hydrazine as a reducing agent [43]. The electrochemical performance of the rGO-based modified electrode showed that the energy, voltage, and coulombic efficiency of the rGO-based electrode were more than $90 \%$ with a stability of up to 65 cycles. The efficiency is comparable to that of pure graphite electrodes used commercially. This is so that the material from biomass-derived rGO has great potential as a substitute for commercial graphite as an electrode material for VRB applications. He et al. in 2011 investigated the properties of graphene paper using chemical reduction [44]. Graphene was prepared in a paper form after synthesis using exfoliation, sonication, homogenization, and the addition of a hydrazine process. Furthermore, it annealed at $80^{\circ} \mathrm{C}$ in a vacuum for $24 \mathrm{~h}$ before being cooled to room temperature. Characterization methods such as Ultraviolet-Visible Spectroscopy (UV-Vis) absorption spectra, Fourier Transform Infrared (FT-IR) spectra, X-Ray Diffraction (XRD), Thermogravimetric Analysis (TGA), Cyclic Voltammetry (CV) and others were implemented to analyze the properties of chemically reduced graphene (CRG). As a result of this research there is the fabrication of stable CRG aqueous dispersions and papers with different reduction levels. Properties of CRG are associated with levels of chemical reduction that can be adjusted and monitored to obtain the desired thermal stability, electrical property or tensile strength, and advanced controlled properties. Chemical reduction of graphene oxide using sodium acetate trihydrate presents its advantages in low-cost, use of non-toxic agent, no hazardous waste and simple product separation processes [45]. Sodium acetate trihydrate is an effective reducing agent in removing most of the oxygen-containing groups from GO for restoring the conjugated electronic structure of graphene.

\section{Electrochemical Method}

Electrochemical reactions mainly consist of cathode, anode, electrolyte, and metallic contact (standard electrochemical cell). The synthesis method of electrochemical reduction has the purpose of returning the actual properties of pristine graphene and of utilizing the reduced graphene (rGO) capability. This method has a resulting product, namely electrochemically reduced graphene oxide (ErGO), which contains graphene structure and properties that are different from pristine graphene. The reduction process is controlled by its potential value, and group of oxygen removal in graphene oxide (GO) by working of the electrode surface. Part of the electrochemical system affected the properties of the ErGO [46].

The pencil core is used as an electrode, a cathode and an anode in research by Liu et al. [47] Electrochemical exfoliation is configured in $1 \mathrm{M}$ aqueous electrolytes $\left(\mathrm{H}_{2} \mathrm{SO}_{4}\right.$ or $\mathrm{H}_{3} \mathrm{PO}_{4}$ ) and is potentially ramped for between $+7 \mathrm{~V}$ and $-7 \mathrm{~V}$ for $5-8 \mathrm{~min}$. The result of this study is that the exfoliated graphene oxide flakes are quite large and have great electrocatalytic activity and toxicity tolerance for an oxygen reduction reaction in alkaline solution. Different electrode materials were conducted by Parvez et al. in 2013 [48] using Platinum ( $\mathrm{Pt}$ ) as a cathode and graphite as an anode. Electrochemical exfoliation is configured in $0.1 \mathrm{M} \mathrm{H}_{2} \mathrm{SO}_{4}$ solutions and is potentially ramped at $+10 \mathrm{~V}$ for $10 \mathrm{~min}$. The result of this study is that the exfoliated graphene has yielded about $60 \%$ and with multiple layers. Moreover, the product has a large sheet size, low oxygen content, and/or high C/O ratio as well as excellent electronic properties. Referring to the two studies above, the perfect electrolyte for an electromechanical system is a high-grade acid such as $\mathrm{H}_{2} \mathrm{SO}_{4}$. Flaking process on graphite is supported by acid electrolyte. 


\section{Ball Milling}

Recently, the current development on the graphene synthesis method has a higher potential, which is improved from another step-like ball milling process. The product actually has a chance to enhance and also be an efficient stage for the synthesis method. Although this method is still being developed, high quality graphene from grinding bulk is hopefully produced on a large scale. Graphene, a ball-milling product, is influenced by the wet and dry conditions. Two forces play an important role in this process, such as shear forces exfoliating large graphene sheets, while normal forces break down graphite flakes [35].

$\mathrm{Wu}$ et al. show the accomplished mechanochemical reactions from the suspension of graphite and polystyrene (PS) solution by a ball-milling process [49]. High electrical conductive PS/graphene nanocomposites are obtained with homogenous mono- or fewlayer graphene sheets. The process is operated by dispersed graphite nanoplatelets in $\mathrm{N}, \mathrm{N}$-Dimethylformamide (DMF) solvent to sonicate and generate it into a ball mill with $300 \mathrm{rpm}$. Mondall et al. used a modified Hummers method and a ball mill with zirconium ball ( $5 \mathrm{~mm}$ diameter) with $800 \mathrm{rpm}$ angular speed to prove the amorphisms of reduced graphene oxides and the removal of oxygen function groups [50].

Lin et al. in 2017 found a new method on graphene synthesis, especially few-layer graphene (FLG) using plasma-assisted ball milling (P-milling) with various media [51]. The ball-milling media used in this experiment are boron nitride $(\mathrm{BN})$, tungsten carbide (WC), zinc oxide $(\mathrm{ZnO})$, iron oxide $\left(\mathrm{Fe}_{2} \mathrm{O}_{3}\right)$, and germanium oxide $\left(\mathrm{GeO}_{2}\right)$. Preparation is done by calcining the expandable graphite at $1000{ }^{\circ} \mathrm{C}$ for $15 \mathrm{~min}$ with a heating rate at $5{ }^{\circ} \mathrm{C} / \mathrm{min}$ under Ar atmosphere. Then, the sample is mixed with tungsten carbide (WC) with a ratio of 1:4 to place it in the ball-milling process. The P-milling process is set up with vibration on a $7 \mathrm{~mm}$ amplitude, $16 \mathrm{~Hz}$ frequency, $15 \mathrm{kV}$ voltage, $1.5 \mathrm{~A}$ current, and $60 \mathrm{kHz}$ discharge frequency. Treatment time is configured at $2 \mathrm{~h}, 5 \mathrm{~h}, 8 \mathrm{~h}$ and $10 \mathrm{~h}$. The result of this process is the 6-layered FLG nanosheets with a high quality after the $8 \mathrm{~h}$ process with WC medium. The layers were formed due to the influence of inductive capacity of the ball-milling media, where it will affect the quality of FLG. The higher the inductive capacity, the lower the layer formed, and the higher the FLG quality. However, the ideal range for the inductive capacity is around 7-8.

\subsubsection{Bottom-Up Approaches}

A bottom-up graphene synthesis method that adjusts to the capability of the material from the building part is by part of the structure. The electron character is influenced by the configurations of atoms that are based on carbon precursors. The benefit of this method is that the size of its setting can be adjusted, so the dimension of the product is predictable. However, this method has several limitations compared to the top-down method, including the low properties obtained (i.e., yield), high cost, and the difficulties in scaling up. The following sections explain the examples of the bottom-up method [35].

\section{Chemical Vapor Deposition (CVD)}

Since 2009, the CVD method has become popular among researchers and has been often used until now. The carrier of this system is an inert gas with a high temperature and vacuum environment to process highly volatile carbon sources. There are many sources of carbon, such as precursors in gases (methane, acetylene, ethylene), liquids (ethanol, methanol), and solids (bio-carbon, polymer, waste plastic). The opportunity of this method lies in the high electrical conductivity that can be widely applied for electronic devices [11].

Li et al. in 2012 implemented a CVD method by keeping electropolished $\mathrm{Cu}$ foils under low pressure and toluene at $500-600{ }^{\circ} \mathrm{C}$ to grow continuous single layer graphene films [52]. As a result, the graphene has been produced with a high sheet resistance, a good transmittance of around $97.33 \%$ at $550 \mathrm{~nm}$ and a good electron mobility of $190 \mathrm{~cm}^{2} /($ V.s. $\mathrm{Li}$ et al. also reported this, but from a different precursor, methane [53]. Copper foil was 
analyzed at a high temperature $\left(1035^{\circ} \mathrm{C}\right)$ under low pressure. The product obtained had a single crystallographic orientation, with a high electron mobility of $4000 \mathrm{~cm}^{2} /(\mathrm{V} . \mathrm{s})$.

Principally, the precursor carbon source and the rate of growth graphene determined the form of the graphene product. Big or small, the graphene size could be adjusted by controlling those two factors. Moreover, the large-area, high quality graphene and the large size of the graphene single crystals with different shapes and layers could be fabricated in case of the managed synthesis parameter due to Liu et al. in 2017 [54].

\section{Arc Discharge}

Arc discharge is a low cost and environmentally friendly synthesized graphene method. The obtained graphene with this method could be done under several circumstances, such as in a hydrogen, helium, or nitrogen state. Few-layered graphene (FLG) is produced under a helium and carbon dioxide mixture as it was in an experiment by Wu et al. in 2010 [55]. Synthesis method is controlled by directing current around 100-200 A, discharging voltage $30 \mathrm{~V}$, and setting up diameter of anode $13 \mathrm{~mm}$ and cathode $40 \mathrm{~mm}$. The result exhibits FLG sheets in organic solvents that can be easily dispersed and have fewer defects than other chemical steps. The capability of the solution used is important for fabricating electrical devices and composite materials.

In 2016, Kim et al. showed the arc discharge process to produce bi- and trilayer graphene using water medium as the dielectric [56]. A DC power supply is used to flow the direct current with amounts $1 \mathrm{~A}$ to $4 \mathrm{~A}$ between cathode and anode, keeping the voltage at about $25 \mathrm{~V}$ to initiate the arc discharge process. To remove the residual solvent, a drying process is needed with heating at around $85^{\circ} \mathrm{C}$ for $2 \mathrm{~h}$. The resulting product has the probability to become a good electrode because it has a high transmittance $(84.5 \%$ at $550 \mathrm{~cm}^{-1}$ ) and an electrical resistivity of $27.7 \mathrm{k} \Omega \mathrm{cm}^{-2}$.

\section{CNT Unzipping}

Multiwalled carbon nanotubes were cut longitudinally by first suspending them in sulphuric acid and then treating them with $\mathrm{KMnO}_{4}$. This produced oxidized graphene nanoribbons, which were subsequently reduced chemically. The resulting graphene nanoribbons were found to be conducting, but were electronically inferior to large-scale graphene sheets due to the presence of oxygen defect sites [37].

Kosynkin et al. in 2009 [57] explained how to get graphene nanoribbons by unzipping CNT. The product obtained was approximately near a $100 \%$ yield of the nanoribbon structure. Mechanism opening is dependent on oxidation alkenes by permanganate acid. Graphene structures were found subsequently in acid conditions $\left(\mathrm{H}_{2} \mathrm{SO}_{4}\right)$ in exfoliating nanotubes.

\subsection{Synthesis Method of Silica-Graphene Hybrid Composites}

A SiO $/$ /graphene composite is a material that has a high specific surface area, good mechanical properties, and good electrical conductivity. Appropriate fabrication methods must be chosen to produce composites with improved physical and chemical properties in order to obtain a high performance [24].

\subsubsection{Hydrothermal}

The hydrothermal method is one of the simplest methods of graphene/silica $\left(\mathrm{G} / \mathrm{SiO}_{2}\right)$ composite synthesis [23]. Graphene/mesoporous silica composites have been successfully synthesized by Qian et al. with one-step hydrothermal method from Tetraethyl Orthosilicate (TEOS) and organic solvents as a carbon source. Hexadecyltrimethylammonium bromide (CTAB) was dissolved with urea and was then added to an organic solvent, isopropanol, and TEOS. It was reacted for $4 \mathrm{~h}$ at $180^{\circ} \mathrm{C}$. The formation mechanism of $\mathrm{G} / \mathrm{SiO}_{2}$ is shown in Figure 1. The result of this experiment shows that graphene and silica layer are simultaneously produced and the distribution of graphene is uniform in the composite. In addition, organic solvents such as hexane, heptane, toluene, benzene, and cyclohexane 
can be used as a carbon source, therefore graphene does not need to use graphite as a carbon source.

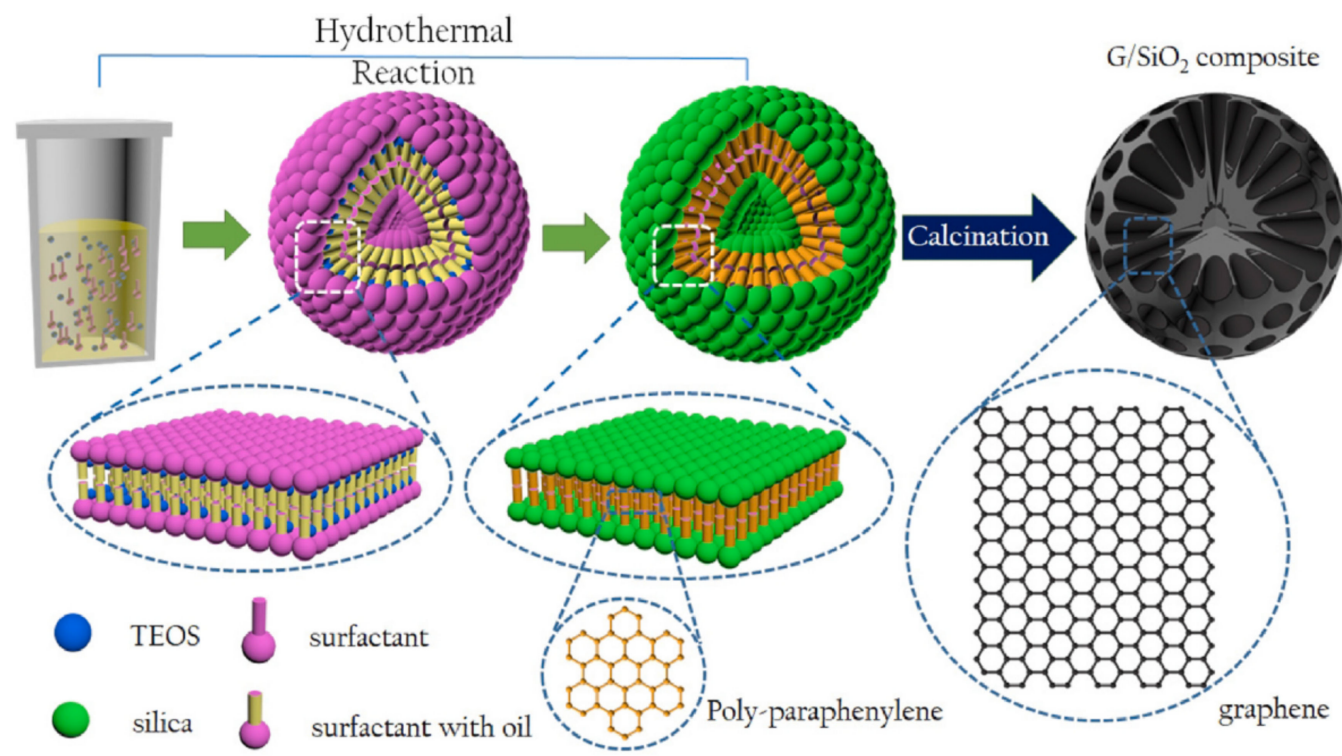

Figure 1. Schematic of $\mathrm{G} / \mathrm{SiO}_{2}$ composite growth mechanism. This figure is reproduced from ref. [23] with the required copyright permission.

TEM image of $\mathrm{G} / \mathrm{SiO}_{2}$ composites prepared with different organic solvents as a carbon source are shown in Figure 2. It is shown that all mesoporous spherical particles with a radial channel structure in the diameter of $0.2-1 \mu \mathrm{m}$ and uniform distribution of graphene in composite were produced from this experiment. The pore size of the prepared $\mathrm{SiO}_{2} @ \mathrm{G} / \mathrm{SiO}_{2}$ particles reaches $17.7 \mathrm{~nm}$.
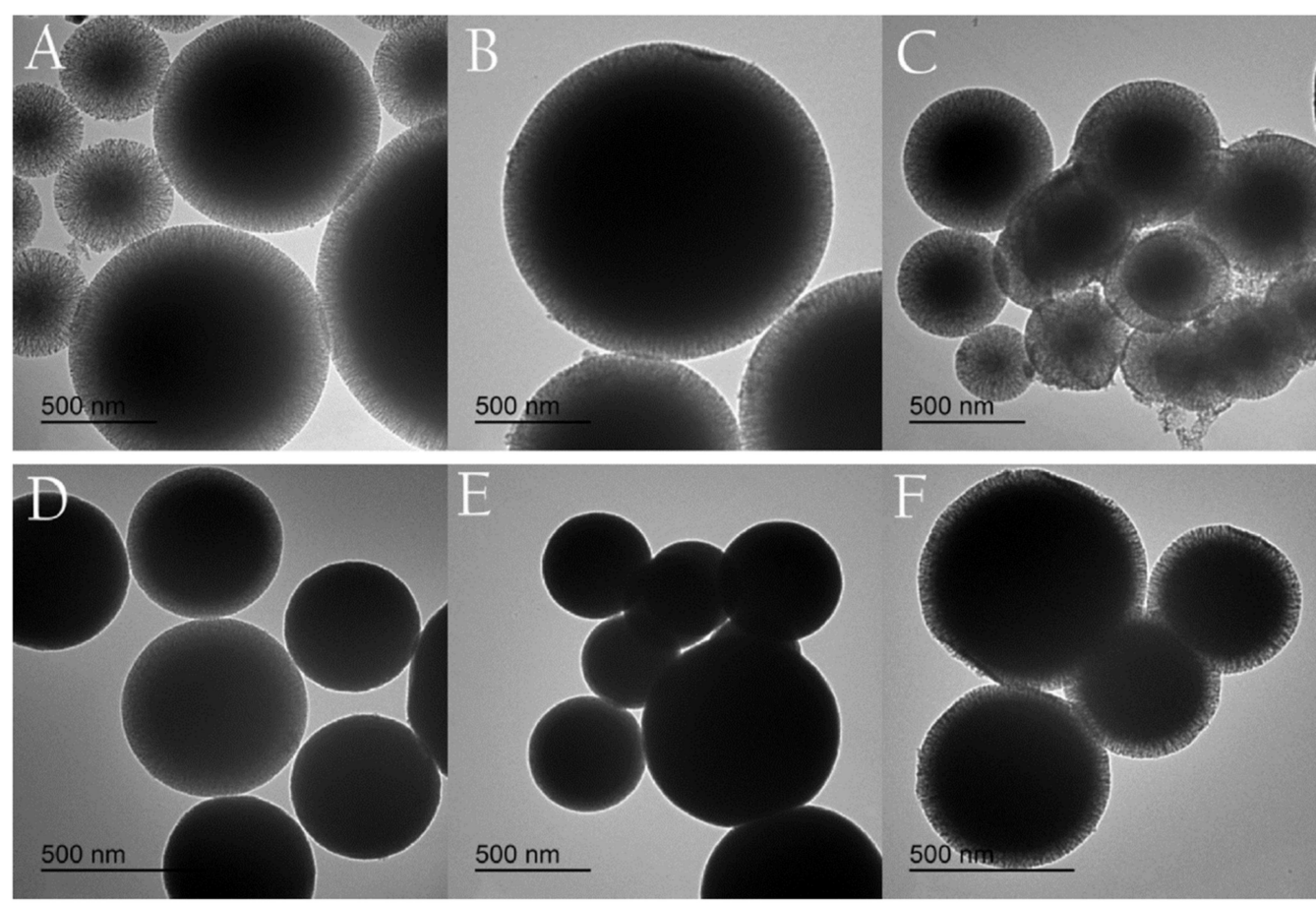

Figure 2. TEM images of $\mathrm{G} / \mathrm{SiO}_{2}$ composites prepared with different organic solvents as carbon sources. (A), toluene; (B), xylene; (C), mesitylene; (D), n-hexane; (E), n-heptane; (F), cyclohexane. This figure is reproduced from ref. [23] with required copyright permission. 
The synthesis of $\mathrm{SiO}_{2}$ nanocomposite/reduced graphene oxide (RGO) has also been successfully synthesized by Yi et al. [58] with a one-step hydrothermal method under acidic conditions using tetraethoxysilane (TEOS) and graphene oxide (GO). Mixtures of GO and $\mathrm{SiO}_{2}$ will undergo a hydrothermal reaction in a cylindrical stainless steel reactor at $120{ }^{\circ} \mathrm{C}$ for $12 \mathrm{~h}$. Along with the TEOS hydrolysis process, silica is loaded on a GO sheet surface with covalent bonds. Experimental results show that $\mathrm{SiO}_{2}$ nanoparticles can be dispersed uniformly on the surface of the RGO. The composite containing $75 \mathrm{wt}$. $\% \mathrm{SiO}_{2}$ has a micromesopore structure with a surface area of $676 \mathrm{~m}^{2} / \mathrm{g}$. The synthesized $\mathrm{SiO}_{2} / \mathrm{RGO}$ samples had an adsorption performance with the efficiency of $\mathrm{Cr}(\mathrm{VI})$ ion removal in wastewater reached equilibrium in $30 \mathrm{~min}$ and the adsorption efficiency of $\mathrm{Cr}(\mathrm{VI})$ reached $98.8 \%$ at $\mathrm{pH}=2$ and temperature $35^{\circ} \mathrm{C}$.

\subsubsection{Sol-Gel}

Sol-gel is one of the methods used to synthesize graphene/silica composites with the advantage of easy control of chemical composition and the ability to form composites with various filling materials [59]. The synthesis of silica/graphene oxide hydrogel has been successfully carried out by Oh Byeolnim et al. using the sol-gel method based on silica hydrogel with a combination of an acid/base catalyst system. From this experiment, it was found that GO was dispersed and did not suffer structural damage. The higher the $\mathrm{GO}$ volume, the faster the gelatinization process so as to minimize the occurrence of GO particle agglomeration. The presence of a catalyst $(\mathrm{NaOH})$ makes the composition in the composite evenly distributed due to the acceleration of the gelatinization process. On the other hand, the hydrogel weakens with increasing GO, but the flexibility increases. It has a modulus of elasticity of $10 \mathrm{kPa}-4.5 \mathrm{MPa}$, the highest compressive strength, compressive strain, and young modulus is about $0.3 \mathrm{Mpa}, 0.35,4.7 \mathrm{Mpa}$.

Haeri et al. in 2017 exhibited two route sol-gel methods for synthesized silicafunctionalized graphene oxide nanosheets (GONs) [60]. The first route of the sol-gel method is running. $5 \mathrm{wt} . \%$ silane mixture (TEOS-60 wt.\% and APTES-40 wt.\%), $80 \mathrm{wt} . \%$ alcohol and $15 \mathrm{wt}$ \% deionized water, then added GO nanosheets with the control pH of 4. For the second route, GO nanosheets are put into a mixture after oligomers formed from interaction between the hydrolyzed TEOS and APTES silane precursors at specific circumstances with $\mathrm{pH} 4$ for $72 \mathrm{~h}$, followed by the sonication process. The resulting surface GONs has coarse and unequal characteristics, and also $\mathrm{SiO}_{2}$ nanoparticles appear a lot for the second method compared with the first method. This is because in second method, silane deposition is converted into $\mathrm{SiO}_{2}$ nanoparticles, whereas in method 1, it was grafted in a GO sheet.

\subsubsection{Hydrolysis}

Wang et al. [61] have successfully synthesized silica/graphene oxide sheets for epoxy composites using one step process with assistance of diethylenetriamine (DETA) or ammonium hydroxide $\left(\mathrm{NH}_{4} \mathrm{OH}\right)$ as catalyst. $\mathrm{GO}$ was prepared from graphite with a modified Hummer's method and $\mathrm{SiO}_{2}$ was prepared from TEOS with hydrolysis and condensation. The $\mathrm{SiO}_{2}$ could be easily formed onto the GO surface by the hydrolysis of TEOS which improved the dispersibility of GO and enhanced interaction with epoxy matrix. It was revealed that the $\mathrm{GO}-\mathrm{SiO}_{2}$ /epoxy composites exhibited higher tensile, flexural and impact strength and modulus than that of GO.

Another work of Silica-Graphene Oxide Hybrid Composite Particles synthesizedwith hydrolysis method was performed by Zhang et al. [62]. Preparation of Si-GO Hybrid Composites were conducted by dispersion GO and TEOS in ethanol and hydrated ammonia was added to the mixture as a catalyst. Successful decoration of silica nanoparticles on layered GO surface by hydrolysis of TEOS in Si-GO composite were ensured by SEM and TEM images depicted in Figure 3c,f, respectively. The results show the success of the synthesis of silica particles on the GO surface. Si-GO hybrid composite particles showed a better thermal stability than GO. The Si-GO hybrid composite-based ER (electrorheology) 
fluid exhibits typical ER characteristics and behaves as a Bingham fluid in the presence of an electric field. ER fluids present a very short relaxation time in dielectric analysis.
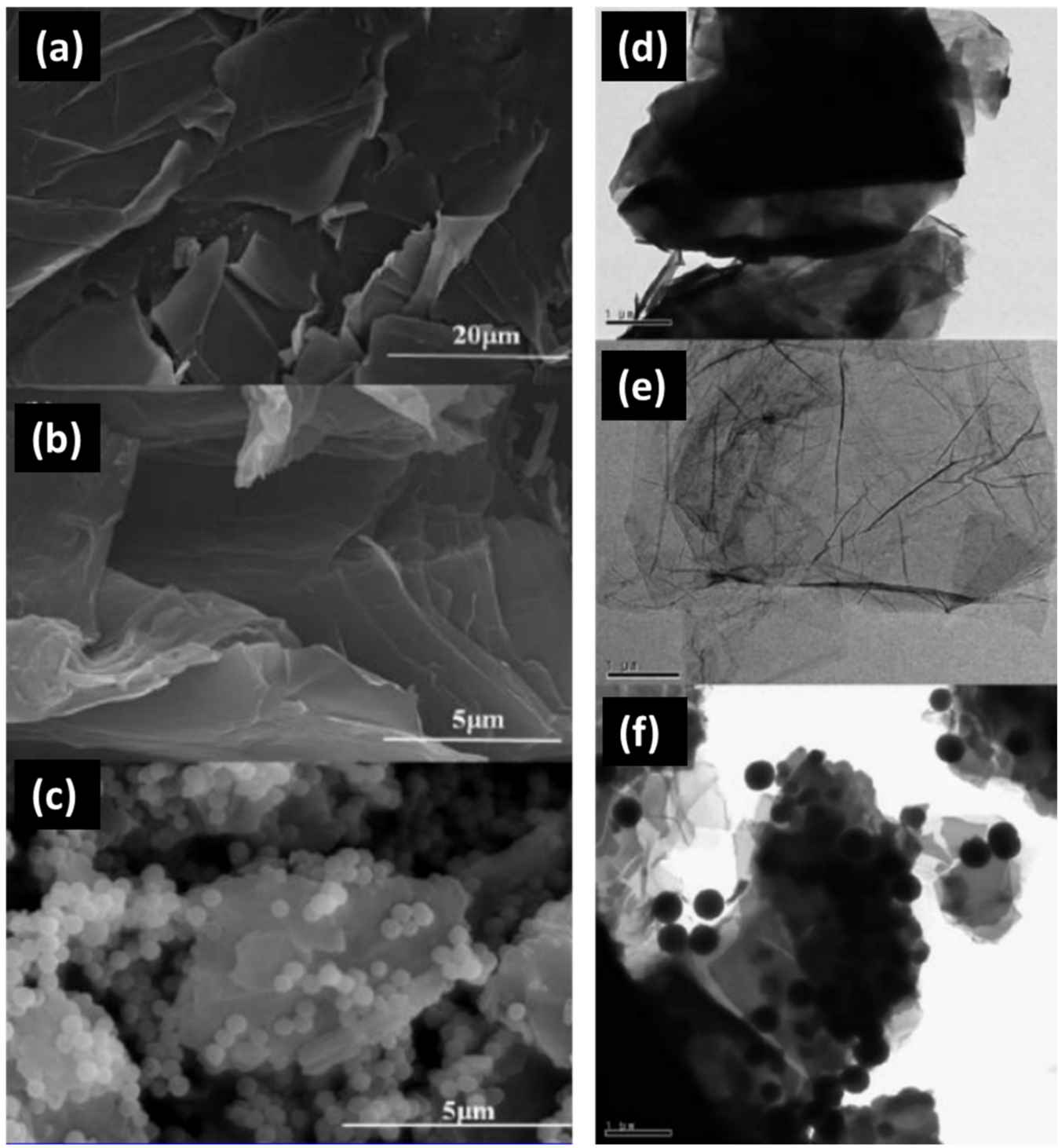

Figure 3. (a) SEM image of pure graphite, (b) SEM image of GO, (c) SEM image of Si-GO hybrid composite (d) TEM image of pure graphite, (e) TEM image of GO, (f) TEM image of Si-GO hybrid composite. This figure is reproduced from ref. [62] with the required copyright permission.

\subsubsection{Encapsulation}

Encapsulation is one of the graphene/silica composite synthesis methods that can produce advantages in increasing silica-epoxy interface adhesion. The GO (graphene) encapsulation core shell hybrid made with an ultra-thin layer GO (graphene) on organic/inorganic objects can provide special properties and applications [63].

The experiment about epoxy/silica composites by introducing graphene oxide to the interface was done by Chen et al. [63] with the core shell method. GO was prepared from natural graphite by the Hummers method and surface modification of $\mathrm{SiO}_{2}$ with an APS coupling agent. The $\mathrm{SiO}_{2}-\mathrm{GO}$ hybrid was fabricated by mixing the suspension of $\mathrm{SiO}_{2}-\mathrm{NH}_{2}$ and the $\mathrm{GO}$ solution. Preparation of epoxy $/ \mathrm{SiO}_{2}-\mathrm{GO}$ composites by dispersion of $\mathrm{SiO}_{2}-\mathrm{GO}$ in tetrahydrofuran solvent. The $\mathrm{SiO}_{2}$ and $\mathrm{SiO}_{2}-\mathrm{GO}$ composite morphology investigated by SEM and HR-TEM reveal that $\mathrm{SiO}_{2}$ particles exhibits smooth surface (Figure 4a), whereas $\mathrm{SiO}_{2}-\mathrm{GO}$ shows that the silica surfaces are intimately covered by 
ultrathin GO with the shell thicknesses less than $3 \mathrm{~nm}$ as depicted in Figure $4 \mathrm{~b}$-d The presence of flexible and very thin GO sheets can be attributed to the creases and rough texture of the composite. Mechanical properties such as Young's modulus, tensile strength, fracture toughness, and elongation are $1.36 \mathrm{GPa}, 51 \mathrm{MPa}, 1.81 \mathrm{MPa} \mathrm{m} 1 / 2$, and $7.36 \%$ respectively. It also has a $\mathrm{Tg}$ of $181.5-209.1^{\circ} \mathrm{C}$. The relatively reduced $\mathrm{Tg}$ values are due to the reduced network density, particle confinement of the filler-matrix interface, and the reduction in organic network density, which dominate the relaxation behavior of epoxy segments.
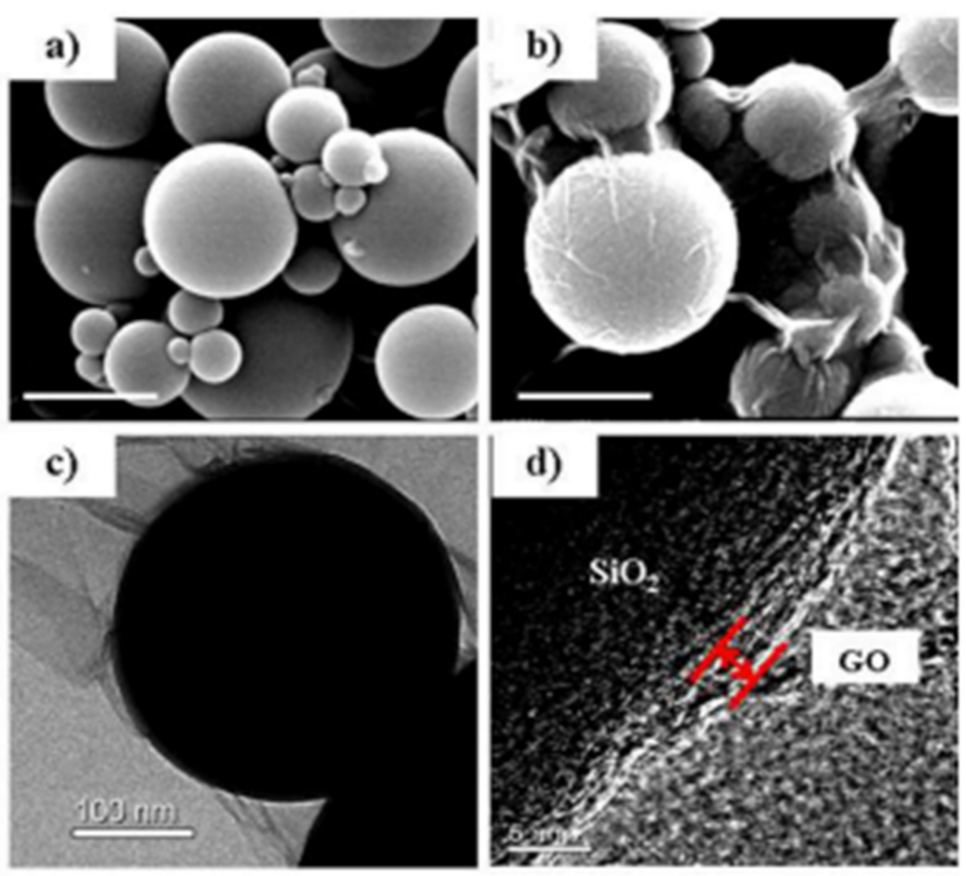

Figure 4. SEM image of (a) Raw $\mathrm{SiO}_{2}$, (b) Created $\mathrm{SiO}_{2}-\mathrm{GO}$ hybrid, TEM of (c) Core shell structured $\mathrm{SiO}_{2}-\mathrm{GO}$ hybrid, (d) Graphene encapsulating silica sphere. This figure is reproduced from ref. [63] with required copyright permission.

The $\mathrm{SiO}_{2} @$ poly (methylmethacrylate)-reduced graphene oxide ( $\mathrm{SiO}_{2} @ \mathrm{PMMA-rGO)}$ composite was successfully synthesized by Ye et al. [64] with the encapsulation method. The synthesis was carried out by dispersion method polymerization and mixing of colloids based on electrostatic assembly. Monodispersed $\mathrm{SiO}_{2}$ nanoparticles with an average diameter of $300 \mathrm{~nm}$ were synthesized by hydrolysis and condensation of TEOS. An aqueous graphene oxide suspension was added to a positively charged $\mathrm{SiO}_{2} @ P M M A$ nanoparticle dispersion with stirring. The resulting product exhibits a high thermal stability with a decomposition temperature increased by $80^{\circ} \mathrm{C}$. Besides that, it also showed strong mechanical properties with a $108 \%$ increase in modulus up to a $125 \%$ increase in hardness. This composite has advantages in thermal stability, a strong mechanical performance, and an excellent conductivity. This method can efficiently avoid the agglomeration of the fused nanofillers as well as improving the interfacial adhesion between the PMMA filler and matrix, so that the resulting composite has a high performance. The strength and weaknesses of several processing methods for graphene/silica composites are compared, as seen in Table 2. 
Table 2. Several processing methods for synthesis of graphene-silica hybrid composites.

\begin{tabular}{|c|c|c|c|c|c|}
\hline No & Composites & Processing Method & Strength & Weakness & Ref. \\
\hline 1 & $\begin{array}{l}\text { Graphene/mesoporous silica } \\
\text { (G/SiO } 2)\end{array}$ & Hydrothermal & $\begin{array}{l}\text { Graphene does not need to be } \\
\text { prepared in advance, graphene } \\
\text { and silica layer overlapped to form } \\
\text { intercalation, uniformly } \\
\text { distribution, organic } \\
\text { solvents can be used as carbon } \\
\text { sources, no toxic gas is generated } \\
\text { during the reaction. It does not } \\
\text { require the use of a catalyst }\end{array}$ & $\begin{array}{l}\text { Graphene can only be made } \\
\text { by adding TEOS as a } \\
\text { precursor, if it is reacted in } \\
\text { big open } \\
\text { space then the rate of } \\
\text { chemical reactions is too slow } \\
\text { to produce } \\
\text { graphene. }\end{array}$ & [23] \\
\hline 2 & $\mathrm{SiO}_{2} / \mathrm{RGO}$ & Hydrothermal & $\begin{array}{l}\text { Efficient method, easy-to-synthesize } \\
\text { process, low cost, composites stability }\end{array}$ & $\begin{array}{l}\text { Control sheet restacking and } \\
\text { aggregation of } \mathrm{SiO}_{2} \\
\text { nanoparticles is required }\end{array}$ & [58] \\
\hline 3 & $\begin{array}{l}\text { Silica/graphene oxide } \\
\text { hydrogel }\end{array}$ & Sol-gel & $\begin{array}{l}\text { Mechanical properties of the } \\
\text { composite hydrogel such as stiffness } \\
\text { can be adjusted by adjusting the } \\
\text { GO contents }\end{array}$ & $\begin{array}{l}\text { Increasing the addition of GO } \\
\text { can weaken and decrease the } \\
\text { mechanical properties of } \\
\text { the hydrogel }\end{array}$ & [59] \\
\hline 4 & $\begin{array}{l}\text { Silica-functionalized } \\
\text { graphene oxide (GO) } \\
\text { nanosheets (GONs) }\end{array}$ & Sol-gel & $\begin{array}{l}\text { Using two different route methods } \\
\text { which produce various results }\end{array}$ & - & [60] \\
\hline 5 & $\begin{array}{l}\text { Silica/graphene oxide sheets } \\
\text { epoxy composites }\end{array}$ & Hydrolysis & $\begin{array}{l}\text { Catalysts (DETA and NH4OH) } \\
\text { improving mechanical properties of } \\
\text { composites by functionalization GO } \\
\text { and forming } \mathrm{SiO}_{2} \text { from a promotion } \\
\text { of the hydrolysis of TEOS on the GO } \\
\text { surface }\end{array}$ & $\begin{array}{l}\text { The mechanical properties } \\
\text { and distribution of the } \\
\text { resulting particles are highly } \\
\text { dependent on the use of } \\
\text { a catalyst }\end{array}$ & [61] \\
\hline 6 & Silica-Graphene Oxide & Hydrolysis & $\begin{array}{l}\text { Relatively simple, inexpensive, and } \\
\text { fast method }\end{array}$ & - & [62] \\
\hline 7 & $\begin{array}{l}\text { Epoxy/silica composites by } \\
\text { introducing graphene oxide }\end{array}$ & Encapsulation & $\begin{array}{c}\text { Interfacial structures and properties } \\
\text { can control by using GO as a novel } \\
\text { coupling agent }\end{array}$ & - & [63] \\
\hline 8 & $\begin{array}{l}\mathrm{SiO}_{2} @ \text { poly(methylmethacrylate)- } \\
\text { reduced graphene oxide } \\
\left(\mathrm{SiO}_{2} @ \mathrm{PMMA-rGO}\right)\end{array}$ & Encapsulation & $\begin{array}{l}\text { Covalent molecular binding and } \\
\text { strongly electrical interaction produce } \\
\text { outstanding thermal stability, } \\
\text { hardness, and electrical conductivity }\end{array}$ & $\begin{array}{l}\text { The morphology of the } \\
\text { composites are strongly } \\
\text { influenced by the } \\
\text { synthesis conditions }\end{array}$ & [64] \\
\hline
\end{tabular}

\section{Applications of Silica-Graphene-Based Hybrid Composites}

\subsection{Adsorbent}

Graphene and its derivatives have the advantage of having a high specific surface area and degrade persistent organic matter chemicals in water, which gives it great potential as an adsorption material for environmental pollutants. Meanwhile, $\mathrm{SiO}_{2}$ has the advantages of being a cheap, non-toxic, and chemically stable material that can overcome the problem of GO aggregation and can increase the specific surface area and adsorption properties. GO has many functional groups containing oxygen, which can absorb heavy metals from wastewater by electrostatic attraction, ion exchange, or surface complexation. Mesoporous silica has good potential in water treatment because of its stable mesoporous structure. Graphene/silica composites as adsorbents for water treatment have advantages over the use of graphene and silica individually because they have a higher adsorption capacity and stability [24].

In the research of Liu et al. [65], synthesis of graphene-silica (GS) composites by anchored nano-zero-valent iron (NZVI) to the surface were used to remove $\mathrm{As}(\mathrm{III})$ and $\mathrm{As}(\mathrm{V})$ from aqueous solution that the maximum capacity reached $45.57 \mathrm{mg} / \mathrm{g}$ and $45.12 \mathrm{mg} / \mathrm{g}$ respectively, by electrostatic attraction and complexation. Mesoporous silica ordered graphene oxide with a two-dimensional mesoporous structure and a large surface area has been synthesized by Wang, et al. (2015) [66] through the sol-gel method. This material is applied as a heavy metal adsorbent in water by adsorption separation-inductively coupled plasma mass spectrometry, that have removal efficiency, for metals $\mathrm{As}, \mathrm{Cd}, \mathrm{Cr}, \mathrm{Hg}$, and $\mathrm{Pb}$ reaching $97.7,96.9,96.0,98.5$, and $78.7 \%$, respectively.

A graphene/silica composite material can be used as an adsorbent for organic pollutants due to their high specific surface area, active site, and good stability [24]. Phenyl- 
modified magnetic graphene/mesoporous silica (MG-MS-Ph) with a hierarchical porebridge structure was synthesized by Wang, et al. (2016) [67], which was applied as a pesticide adsorbent from wastewater. The resulted composite has a surface area of $446.5 \mathrm{~m}^{2} / \mathrm{g}$ with very regular mesopores, a uniform pore size of $2.8 \mathrm{~nm}$, a pore volume $0.32 \mathrm{~cm}^{3} / \mathrm{g}$, and a high saturation magnetization of $25 \mathrm{emu} / \mathrm{g}$. The synthesis of the porous magnetic silica-graphene oxide hybrid composite $\left(\mathrm{Fe}_{3} \mathrm{O}_{4} @ \mathrm{mSiO}_{2} / \mathrm{GO}\right)$ was successfully carried out by Liu, et al. (2014) [68] through the core-shell method to be applied as a p-nitrophenol adsorbent from an aqueous solution. The maximum adsorption capacity produced reached $1548.78 \mathrm{mg} / \mathrm{g}$ at a solution $\mathrm{pH}$ of 8 and a temperature of $25^{\circ} \mathrm{C}$.

The adsorbent commonly used for $\mathrm{CO}_{2}$ is an activated porous solid adsorbent such as carbon, zeolites, and metal-organic frameworks. Graphene coupled with silica also has a good performance as a $\mathrm{CO}_{2}$ adsorbent by increasing its pores [24]. Wang, et al. (2019) [69] used a $2 \mathrm{D} / 3 \mathrm{D}$ structure of reduced graphene-silica oxide (G-Si) aerogel combination using mesoporous silica SBA-15. These special 2D/3D morphological features result in the high $\mathrm{CO}_{2}$ absorption capacity of $6.02 \mathrm{mmol} / \mathrm{g}$ as seen in Figure $5 \mathrm{a}$. In addition, equilibrium is achieved very quickly within the first $12 \mathrm{~min}$ for 30-50 wt\% of TEPA loading indicating that $\mathrm{CO}_{2}$ gas molecules diffused freely throughout G-Si aerogel and SBA-15 as shown in Figure $5 \mathrm{~b}$. Another $\mathrm{CO}_{2}$ adsorbent that has also been successfully synthesized is the reduced amine/graphene oxide (AMS/RGO) modified silica hybrid composite by Vinodh, et al. with a limited growth methodology, which the RGO introduced into the amino alkyl siloxane matrix. This composite shows a good absorption capacity (15\% by weight) and a Maximum $\mathrm{CO}_{2}$ adsorption up to $14.7 \%$.
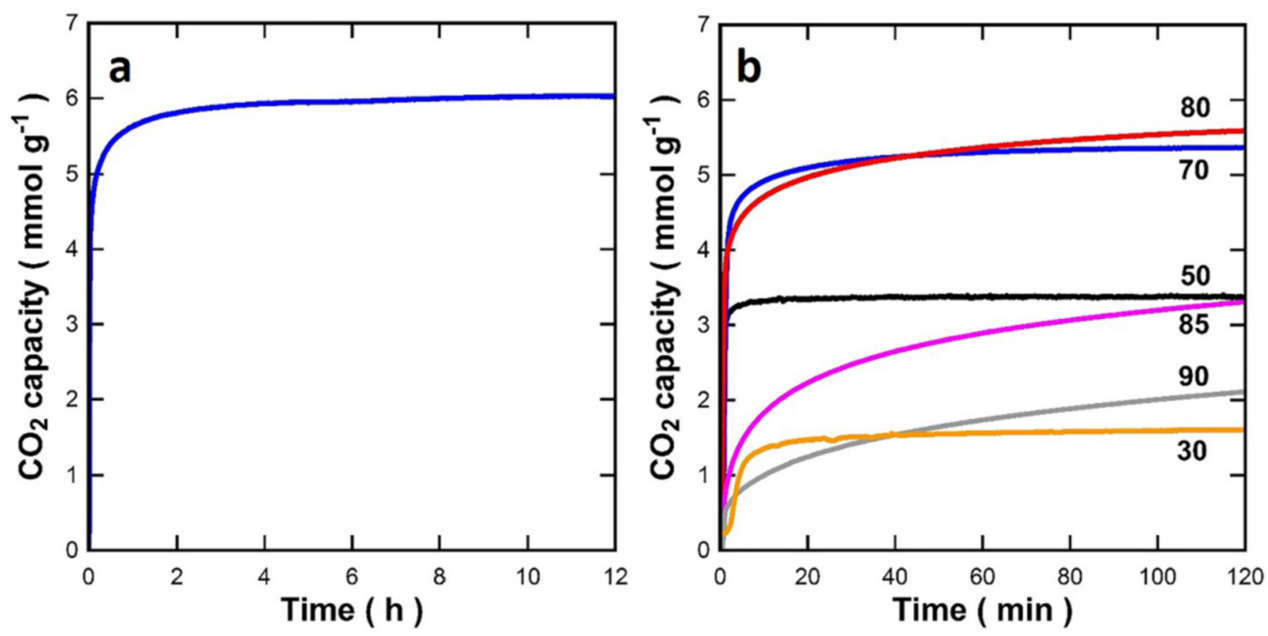

Figure 5. $\mathrm{CO}_{2}$ sorption kinetics of (a) 2D/3D G-Si aerogel/SBA-15 (4.7 wt.\%) loaded with TEPA $80 \mathrm{wt} . \%$ and (b) short term isotherms by varying the TEPA loading. This figure is reproduced from ref. [69] with the required copyright permission.

\subsection{Energy Storage}

Many sources have stated that graphene has high expectations on building energy storage equipment. Great properties in the electrical field required an important role in constructing it. A combination between graphene structures and other materials such as silica provides the strengthened characteristics of composite [11]. Graphene can be formed into the three-dimensional graphene aerogel type, consisting of interconnected graphene sheets and loaded materials. Furthermore, important properties, such as mechanical and electrical ones, are preserved approaching the structures [70].

In the last decade, power saving technology to store energy has been developed in several ways, such as through batteries, capacitors, and others. Electrochemical capacitors (Ecs), commonly called supercapacitors, are devices with a high power capacity and a long cycle life (>100,000 cycles) which required minimal maintenance, and fast charging [71]. Research in this field has attractive value, due to its potential resource as an energy 
storage component. Ghosh et al. (2018) [72], by using the sol-gel method, synthesized a layer-by-layer composite that contained reduced graphene oxide (rGO) and iron silicate in glass. From that study it was found that the specific capacitance for the composite is $370 \mathrm{~F} / \mathrm{g}$, ranked in high grade for supercapacitor applications. This is because of a multilayer structure from rGO and iron silicate glass supporting the properties, such as a large surface area, swinging bonds, high electrical conductivity, and a racking porosity. A multilayer concept, such as an electrode capacitor, is also applied and was analyzed by Kim et al. (2015) [73] A vacuum channel was performed to understand the electrical and photodetection properties of the resulting product. A high responsivity for the structure of about $1.0 \mathrm{~A} / \mathrm{W}$ at $633 \mathrm{~nm}$ was discovered and there is the hope for a capacitance of around $10 \mathrm{nF} / \mathrm{cm}^{2}$ for $1 \mu \mathrm{m}$ depletion.

In the research of Abbas, et al., reduced graphene oxide (rGO) from waste coffee bean biomass is used as an alternative electrode material for the VRB (Vanadium redox flow battery) system. The resulting rGO exhibited more than $90 \%$ energy, voltage and coulombic efficiency, which was comparable to that of commercially used pure graphite electrodes. This electrode also has a stable cyclic performance for 65 cycles due to its high electrocatalytic activity and its enhanced charge transfer [43].

Another type of graphene form-aerogel—shapes the three-dimensional graphene that maintains interesting properties such as a large specific area, flexibility, and conduction. Furthermore, it could be implemented in catalysis, sensing, energy storage and others [70]. Du et al. in 2018 [74] investigated the effect of the addition of amino-functionalized silica as a template and doping agent for $\mathrm{N}$-doped graphene aerogel. The forming structure is an $\mathrm{N}$-doped rGO aerogel with a filling of $\mathrm{SiO}_{2}-\mathrm{NH}_{2}$ particles between the spaces and it has a macroscope diameter of around $50 \mu \mathrm{m}$. The number of $\mathrm{SiO}_{2}-\mathrm{NH}_{2}$ particles has an opposite value with a pore size of rGO aerogel; when it is higher the pore size it will be smaller, but the number of pores will increase. Electrochemical properties from the structure can be identified as the high specific capacitances of $350 \mathrm{~F} / \mathrm{g}$ at the current density of $1 \mathrm{~A} / \mathrm{g}$ with a great reversibility of $88 \%$, a cycling efficiency after 10,000 cycle, and is supported by other properties like a specific large surface area pf $481.8 \mathrm{~m}^{2} / \mathrm{g}$, a low series resistance and a high nitrogen doping content of about 4.4 atom $\%$ so that the composites are reliable as the components of a capacitor with a high oil-absorbability and recyclability.

Along with the rapid development of technology, the need for energy is also getting higher. An energy-saving concept with promising future prospects is lithium-ion batteries. The allocation of excellent properties other than energy storage, such as a high energy and power density, good durability, and environmental buddies, are impressively used in electric vehicle applications. However, this requires special attention for operating it under the limitation of voltage and temperature [75]. Graphene and silica combined were able to act as the electrode of lithium batteries, both anode and cathode. In 2013, Li et al. [76] mapped out the anode from a combination of graphene oxide and $\mathrm{SiO}_{2}$ nanoparticles by an annealing process. Three-dimensional graphene networks were formed owing to great properties such as reversible capacity $(610.9 \mathrm{mAh} / \mathrm{g}$ at $50 \mathrm{~mA} / \mathrm{g}$ after 50 cycles) and superb rate capability (291.5 mAh/g at $5000 \mathrm{~mA} / \mathrm{g})$. Considered as the electrode because of high power density, there was a large porosity and a high electrical conductivity based on the attribute of network structure. In addition, the anode can be designed by a self-assembly process as done by Yin et al. (2017) [77], Wang et al. (2018) [78] and Kim et al. (2018) [79].

Self-assembly procedures to construct the anode lithium-ion battery were done by Yin et al. [77] using ultrasonic-assisted hydrothermal and heat treatments. The unification process considered the mass ratio of all the materials used (colloidal silica, sucrose, and graphene oxide), playing an important role in this manner. Setting up the ratio of silica to sucrose of 0.15 exhibited a great electrical performance, such as discharge capacity (906 $\mathrm{mA} \mathrm{h} / \mathrm{g}$ ) and reversible capacity (542 mAh/g at $100 \mathrm{~mA} / \mathrm{g}$ after 216 cycle). A uniformly dispersed order of small $\mathrm{SiO}_{2}$ nanoparticles in the composites display the high properties (good conductivity) with a simple method implied [77]. An applied convenient method by a facile electrostatic self-assembly approach for obtaining nano-Si/reduced graphene oxide 
porous composite as anode of Li-ion battery application, Wang et al. [78] forfeiting $\mathrm{SiO}_{2}$ as a sacrificial template. The composites consist of nano- $\mathrm{SiO}_{2}$ particles evenly spread across rGO sheets that can intensify electronic conductivity. According to the result as depicted in Figure 6, electrochemical performances increase with the great reversible capacity (1849 $\mathrm{mAh} / \mathrm{g}$ at $0.2 \mathrm{~A} / \mathrm{g}$ ) along with a decent capacity retention, and a high rate capability (535 $\mathrm{mAh} / \mathrm{g}$ at $2 \mathrm{~A} / \mathrm{g}$ ) [78]. Kim et al. [79] reported that the novel structure consists of graphene nanocomposite with ordered mesoporous carbon-silica-titania using one-pot evaporationinduced. Mobility of ions is supported by the regular form of mesopores, which can assist in the transport of electrons in the graphene sheets and the penetration process in electrolytes. Furthermore, the structure clarifies the reason why it can be appropriate for electrodes. Within a high reversible capacity $(547 \mathrm{mAh} / \mathrm{g}$ ) and an efficient reversibility $(65 \%)$, there is an increasing cycle work besides the large structural area [79].

On the other hand, this was also done for cathode of lithium-sulfur batteries by Kim et al. in 2014 [80] by using mesoporous-graphene silica that was infiltrated with sulfur on the organic liquid (polysulfide) electrolyte, resulting in the composite structure with a good electrochemical performance. Respectively, the electrical properties reported for cycling stability and reversible capacity were about $500 \mathrm{mAh} / \mathrm{g}$ and $380 \mathrm{mAh} / \mathrm{g}$ after 400 cycles. To be more convincing, further research was needed to discover the properties of this structure [80].

For solar energy conversion, alternative power saving, the best strategy for hydrogen production is photoelectrochemical (PEC) water splitting based on semiconductor electrodes. In 2018, Zhao et al. [81] analyzed the function and synergy effect of silane molecules and $\mathrm{GO}$ in $\mathrm{WO}_{3}$ nanosheets array $\left(\mathrm{WO}_{3} \mathrm{NS}\right.$ ), where the $\mathrm{WO}_{3} \mathrm{NS}$ was already grafted by silane molecules to make an external electric field (EEF). The result product possessed a high photocurrent of $1.25 \mathrm{~mA} / \mathrm{cm}^{2}$ at $1.23 \mathrm{~V}$ vs RHE, rising 1.8 times as before. The important role of silane for this structure was a hole-storage spot together with GO being a hole-transfer pathway, carrier for channel, and increasing reactive site to promote water oxidation kinetics.

\subsection{Biomedical Fields}

GO has good biocompatibility, low toxicity, water solubility, and easy surface modification, which makes it attractive in the biomedical field. Meanwhile, silica nanoparticles have excellent biocompatibility, encapsulation ability in hydrophilic and hydrophobic molecules, high surface area, tunable morphology, and scalable synthetics availability. This makes the combination of graphene and silica in composites have a high potential for application in medical fields such as drug carriers, imaging, diagnosis, and therapy [24].

Research conducted by He, et al. [82] with the assembly of reduced graphene oxide (RGO) and mesoporous silica grafted with an alkyl chain (MSN-C18) for application as a drug carrier on exposure to near-infrared light (NIR). This material has a structure formed by the noncovalent interaction of the RGO cap and the alkyl chain at the MSN-C18 surface. There is an unlocking mechanism on this material that allows the loaded drug molecules to be released by irradiating NIR light. These drug carrier agents can be a promising drug delivery system for cancer therapy. 

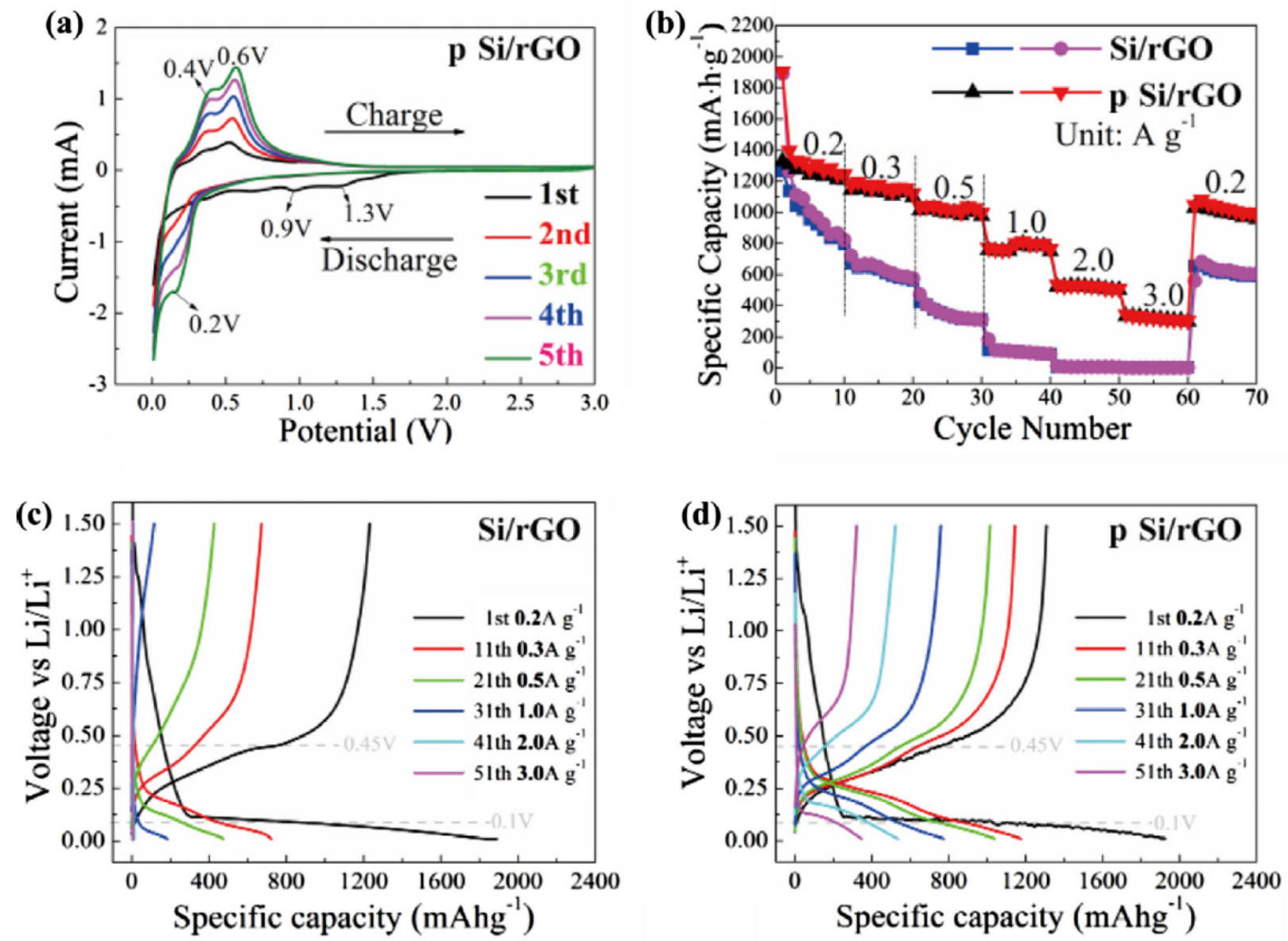

(e)

(f)
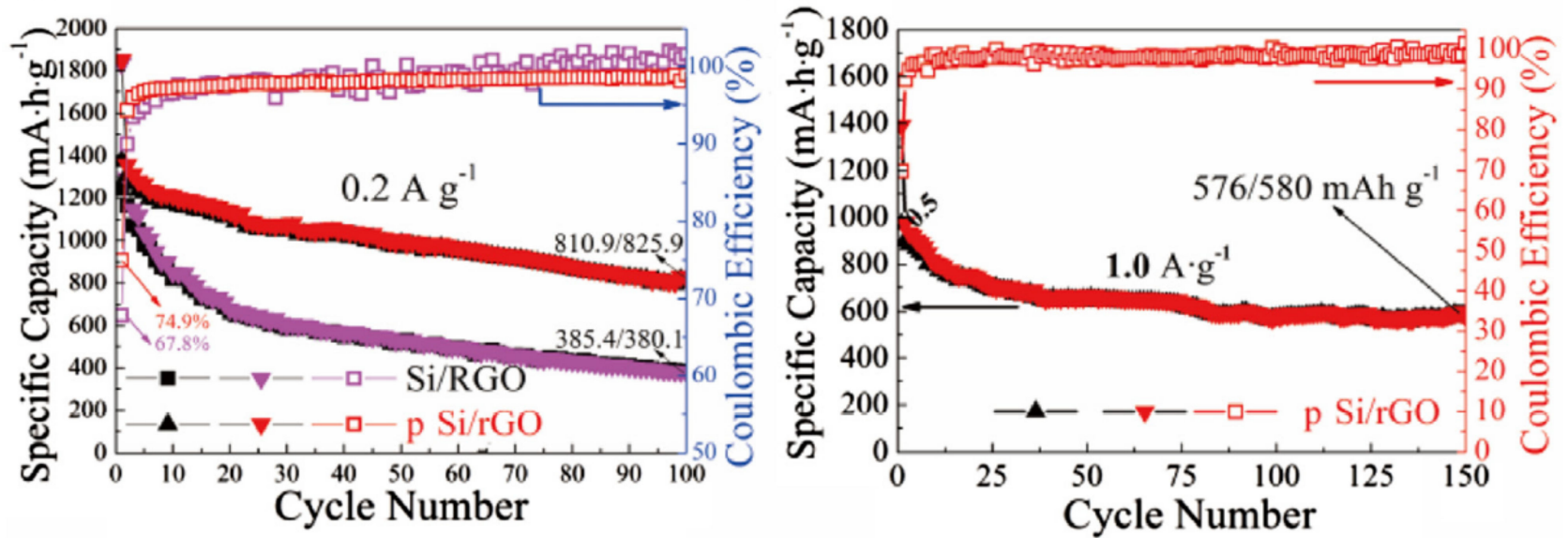

Figure 6. (a) $\mathrm{CV}$ curves of $\mathrm{p} \mathrm{Si} / \mathrm{rGO}$ at a scanning rate of $0.1 \mathrm{mV} \mathrm{s}^{-1}$ in the potential range of $0.01-3.0 \mathrm{~V}\left(\mathrm{vs} . \mathrm{Li} / \mathrm{Li}^{+}\right.$). (b) Rate capability of $\mathrm{p} \mathrm{Si} / \mathrm{rGO}$ and $\mathrm{Si} / \mathrm{rGO}$. Galvanostatic discharge/charge curves of (c) $\mathrm{Si} / \mathrm{rGO}$ and (d) p Si/rGO; (e) Cycling performance of $\mathrm{p} \mathrm{Si} / \mathrm{rGO}$ and $\mathrm{Si} / \mathrm{rGO}$ at $0.2 \mathrm{~A} \mathrm{~g}^{-1}$; (f) Cycling performance of $\mathrm{p} \mathrm{Si} / \mathrm{rGO} 1.0 \mathrm{~A} \mathrm{~g}^{-1}$ in a potential range of $0.01-1.5 \mathrm{~V}$ vs. $\mathrm{Li} / \mathrm{Li}^{+}$. The loading mass of active material is $1.1 \mathrm{mg} / \mathrm{cm}^{2}$. This figure is reproduced from ref. [78] with required copyright permission.

Mesoporous silica nanoparticles (MSNPs) coated in blue fluorescent N-graphene quantum dots, loaded with DOX drug, and finally coated with hyaluronic acid (HA), was synthesized by Gui, et al. [83] for intracellular delivery of the cancer drug doxorubicin (DOX) to specific targeting of tumor cells. Imaging of human cervical carcinoma (HeLa) cells may arise as a result of cellular uptake of NPs with HA-DOX-GQD@MSNPs type architecture via fluorescence microscopy. Song, et al. [84] have designed a multifunctional 
probe incorporating active-targeted fluorescent imaging (FL)/photoacoustic imaging (PA) and chemo-photothermal therapy for tumors. Modified graphene oxide (GO) folate (FA) molecules were used to coat core-shell silver sulfide@mesopore silica (QD@Si) for loading the antitumoral doxorubicin (DOX) on mesoporous channels by the presence of electrostatic adhesion, and a delivery system (QD@Si-D/GO-FA) for active targeted dual-mode imaging and synergistic chemo-photothermal for tumors. The obtained cell survival rate was $76.3 \pm 4.6 \%$, which indicates that the probe has good biocompatibility. Tumors can be effectively killed at an increase in temperature to $63.5^{\circ} \mathrm{C}$ under laser irradiation with combination chemotherapy due to the presence of GO exfoliation from QD@Si-D/GO-FA after irradiation.

In the study of Shao, et al. [85], mesoporous silica-coated polydopamine (MS)-fused reduced graphene oxide (pRGO) with modified hyaluronic acid (HA) (pRGO@MS-HA) has been used for cancer chemo-photothermal therapy as seen in Figure 7. This material is used to enhance doxorubicin (DOX) loading, with good dispersibility, excellent photothermal and tumor cell killing efficiency, and a specificity for targeting tumor cells, which is better than any monotherapy.

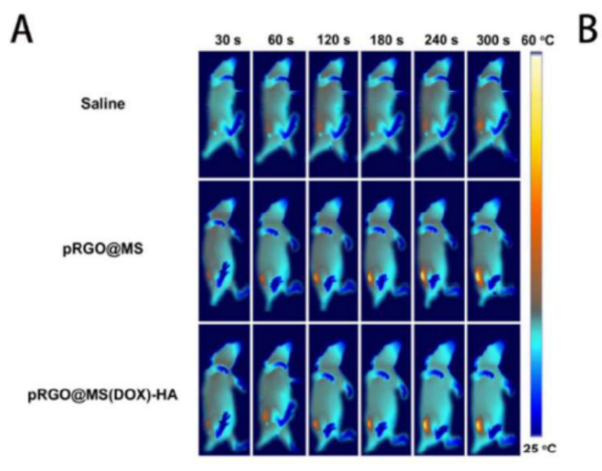

C

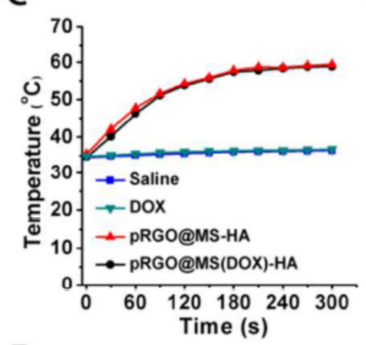

D

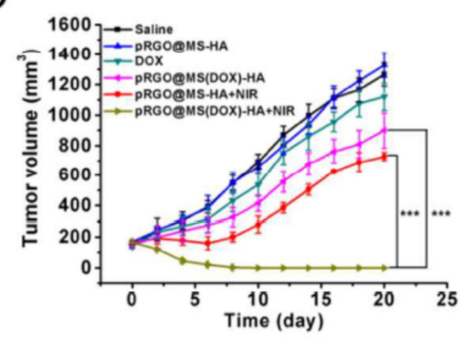

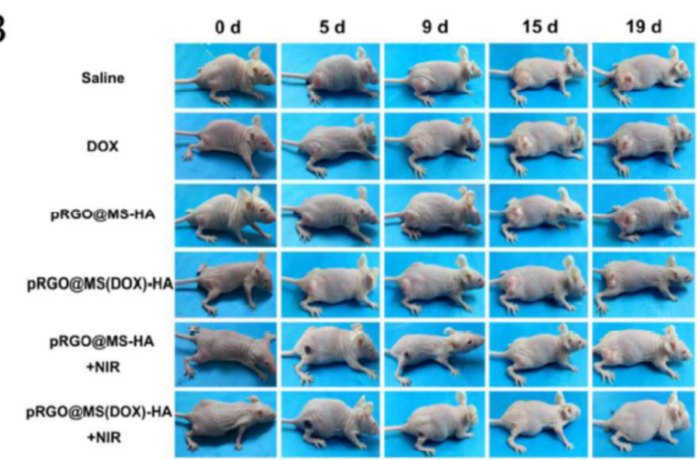

$\mathrm{E}$

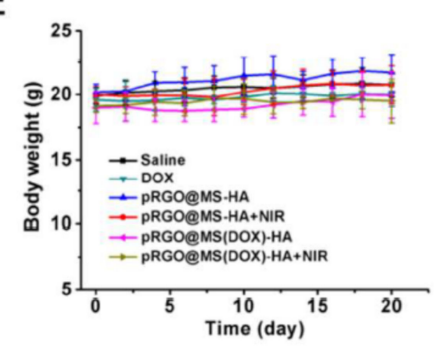

$\mathrm{F}$
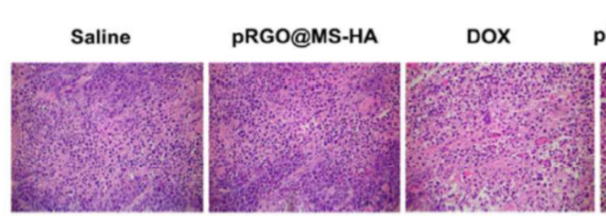

PRGO@MS(DOX)-HA

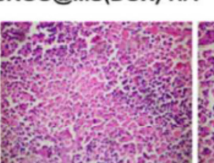

PRGO@MS-HA pRGO@MS(DOX)-HA

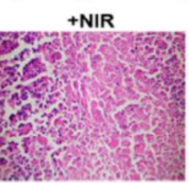
+ NIR

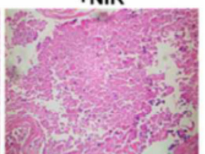

Figure 7. In vivo anti-tumor activity of pRGO@MS(DOX)-HA nanocomposite. (A) IR thermal images of HeLa tumor-bearing mice upon $808 \mathrm{~nm}$-laser irradiation for different periods of time. (B) Representative images of mice bearing HeLa tumors after different treatments for varied time periods. (C) Temperature variation curves of tumor regions recorded by the IR thermal camera during NIR laser irradiation. (D) Tumor growth curves of mice after various treatments (five mice for each group). (E) The average body weights of mice after various treatments. (F) Representative H\&E sections of tumors after treatment with saline, DOX, pRGO@MS-HA, pRGO@MS-HA+NIR, pRGO@MS(DOX)-HA, pRGO@MS(DOX)-HA+NIR. This figure is reproduced from ref. [85] with the required copyright permission. 


\subsection{Catalysis}

By using a two-step reduction method, purposely to make sandwich nanostructure electrocatalyst that contain silica nanosphere filled palladium encapsulated with graphene (denoted $\mathrm{Pd} / \mathrm{SiO}_{2} @ \mathrm{RGO}$ ), this study has been research by Yang et al. in 2018. [86] The product has several advantages, mainly in methanol electrooxidation. There are $\mathrm{SiO}_{2}$ particles that help the spreading of Pd NPs and prevent the aggregation of rGO, and also moderate the rGO strategy. $\mathrm{Pd} / \mathrm{SiO}_{2} @ \mathrm{RGO}$ shows an excellent durability because it has the highest retained current density of $308.5 \mathrm{~mA} / \mathrm{mg}$ and the lowest current decay speed of $19.3 \%$ during $1500 \mathrm{~s}$.

In 2018, Nguyen et al. [87] find out for an photocatalytic application under visible irradiation by using convenient simple self-assembly to mixing lanthanum copper sulfur $\left(\mathrm{LaCuS}_{2}\right)$ with mesoporous silica and graphene oxide, in order to shape a new ternary catalyst. The result has a pore size of around $5.83 \mathrm{~nm}$ with excellent photocatalytic characteristics. Under $\mathrm{pH} 11$, the rate degrades by almost $100 \%$ until $\mathrm{pH} 9$, which means an enhanced dye removal percentage. Furthermore, the optimum amount is $0.05 \mathrm{~g}$ for the gallic acid photocatalytic, which refers to good photocatalytic performances [87]. On the other hand, Oh et al. [88], uses TEOS and cetyltrimethylammonium bromide (CTAB) on a self-assembly method to create mesoporous $\mathrm{SiO}_{2} / \mathrm{CdO}$-graphene composites (SCdOG). The result of the photocatalytic degradation achieves almost 100\% Methylene Blue (MB) organic dye removal after the adsorption equilibrium for $2 \mathrm{~h}$, as shown in Figure 8. Furthermore, the adsorption capability was the highest in the case of MB dye, compared with the other dyes. Besides that, this work opens a way to elevate the photocatalytic activity of gallic acid at ambient conditions without any further different oxidation processes, as well as for developing an efficient hetero-system for hydrogen production.

The composite that contains mesoporous silica layers within an encapsulating graphene nanosheet supported by an ultrafine metal was studied by Shang et al. in 2014 [89], and was developed by Sarkar et al. in 2019 [90] by changing metal uses with $\mathrm{Cu}$. Besides producing the structure with the desire properties, their research is also trying to provide a catalyst which can be useful in chemical reactions. Shang et al. found catalysts with high activity and stability, and great recycling and reusability. Catalytic performance is enhanced by $\mathrm{SiO}_{2}$ layers, and can be deactivated by feedstock poisoning.

Here, the applications and challenges for graphene/silica composites are compared as seen in Table 3.

From the application of graphene-silica hybrid composite, we summarized the properties of graphene, silica and graphene/silica composites and its potential applications which is depicted in the Table 4: 

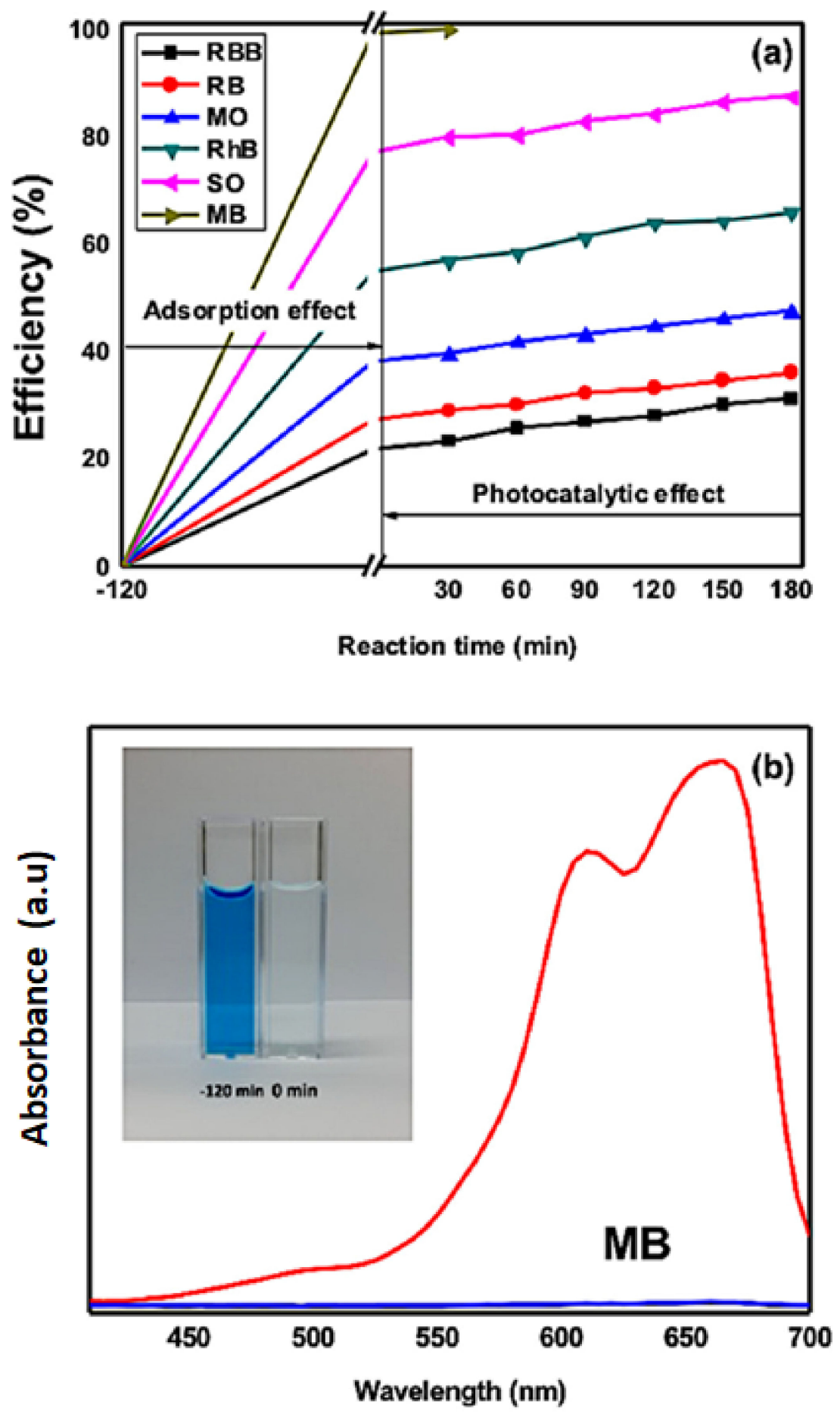

Figure 8. (a) SCdOG nanocomposite for the different cationic dyes degradation under visible light irradiation. (b) Adsorption capability of SCdOG nanocomposites for MB removal.The experiments were carried out with a neutral $\mathrm{pH}$. This figure is reproduced from ref. [88] with the required copyright permission. 
Table 3. Applications of graphene-silica hybrid composites, advantages and challenges.

\begin{tabular}{|c|c|c|c|c|c|}
\hline No & $\begin{array}{l}\text { Applications of } \\
\text { Graphene/Silica } \\
\text { Composites }\end{array}$ & Method & Advantages & Challenge & Ref. \\
\hline 1 & $\begin{array}{c}\text { Adsorbent for } \mathrm{As}(\mathrm{III}) \text { and } \\
\mathrm{As}(\mathrm{V}) \text { from } \\
\text { aqueous solution }\end{array}$ & $\begin{array}{l}\text { electrostatic attraction } \\
\text { and complexation }\end{array}$ & $\begin{array}{l}\text { Can be composited with } \\
\text { other materials to increase } \\
\text { absorption efficiency }\end{array}$ & $\begin{array}{l}\text { Dependent on } \mathrm{pH} \text { of the } \\
\text { solution, unable to reach } \\
\text { WHO drinking water } \\
\text { standard }\end{array}$ & [65] \\
\hline 2 & $\begin{array}{l}\text { Adsorbent for heavy metal } \\
\text { As, } \mathrm{Cd}, \mathrm{Cr}, \mathrm{Hg} \text {, and } \mathrm{Pb}\end{array}$ & Sol-gel & $\begin{array}{l}\text { Low-cost, environmental } \\
\text { friendly } \\
\text { synthesis method, highly } \\
\text { efficient adsorption }\end{array}$ & $\begin{array}{l}\text { Complicated manufacturing } \\
\text { process }\end{array}$ & [66] \\
\hline 3 & Adsorbent for pesticides & $\begin{array}{l}\text { One-step solvothermal } \\
\text { and one-step method }\end{array}$ & $\begin{array}{l}\text { Low cost and efficient } \\
\text { adsorbents }\end{array}$ & $\begin{array}{c}\text { low concentrations } \\
\text { pesticides in complex } \\
\text { wastewater. }\end{array}$ & [67] \\
\hline 4 & $\begin{array}{l}\text { Adsorbent for } \\
\text { p-nitrophenol }\end{array}$ & Grafting and core-shell & $\begin{array}{l}\text { High adsorption capacity, } \\
\text { composites could be easily } \\
\text { separated from solutions } \\
\text { through an external } \\
\text { magnetic force }\end{array}$ & $\begin{array}{l}\text { The introduction of } \mathrm{SiO}_{2} \\
\text { and } \mathrm{GO} \text { will reduce the } \\
\text { magnetization so that an } \\
\text { external magnetic field } \\
\text { is needed, } \\
\text { the rate of diffusion slows } \\
\text { down in the first stage }\end{array}$ & [68] \\
\hline 5 & $\begin{array}{l}\text { Adsorbent for } \\
\mathrm{CO}_{2} \text { capture }\end{array}$ & Freeze-drying method & $\begin{array}{l}\text { High } \mathrm{CO}_{2} \text { sorption } \\
\text { capacity, very stable } \\
\text { under sorption }\end{array}$ & $\begin{array}{l}\text { Morphological feature of the } \\
\text { 2D/3D sorbent assembly is } \\
\text { attributed to decreasing } \\
\text { surface area and pore } \\
\text { volume, very slow } \\
\text { sorption kinetics }\end{array}$ & [69] \\
\hline 6 & $\begin{array}{c}\text { Energy storage: electrode } \\
\text { material in } \\
\text { supercapacitors }\end{array}$ & Sol-gel & $\begin{array}{l}\text { specific capacitance of the } \\
\text { composite is considerably } \\
\text { higher than that of } \\
\text { graphene and has good } \\
\text { cyclic stability as electrode } \\
\text { material for } \\
\text { supercapacitor }\end{array}$ & $\begin{array}{l}\text { The measurement of } \\
\text { temperature dependent } \\
\text { resistance for the composite } \\
\text { in the } \\
\text { temperature range from } 5 \\
\text { K-300 K was performed } \\
\text { under cycle cryostat and } \\
\text { high vacuum condition }\end{array}$ & [72] \\
\hline 7 & $\begin{array}{l}\text { Energy storage: } \\
\text { supercapacitor electrode }\end{array}$ & Hydrothermal method & $\begin{array}{c}\text { Ultrahigh specific } \\
\text { surface area, } \\
\text { high capacitance and } \\
\text { long lifetime }\end{array}$ & $\begin{array}{l}\text { Need high temperature } \\
\text { annealing process }\end{array}$ & [74] \\
\hline 8 & $\begin{array}{c}\text { Energy storage: as anode } \\
\text { materials of lithium } \\
\text { lithium-ion batteries }\end{array}$ & $\begin{array}{l}\text { Hydrothermal method } \\
\text { and heat treatments }\end{array}$ & $\begin{array}{c}\text { enhance the electrical } \\
\text { conductivity, and improve } \\
\text { the electrochemical } \\
\text { performance. }\end{array}$ & & [77] \\
\hline 9 & $\begin{array}{c}\text { Energy storage: Lithium } \\
\text { battery } \\
\text { electrode }\end{array}$ & $\begin{array}{l}\text { electrostatic } \\
\text { self-assembly } \\
\text { method }\end{array}$ & $\begin{array}{l}\text { Enhance the electronic } \\
\text { conductivity, provide } \\
\text { more transfer channels for } \\
\text { Li+, excellent } \\
\text { electrochemical } \\
\text { performance }\end{array}$ & $\begin{array}{l}\text { The } \mathrm{pH} \text { value of process } \\
\text { needs to be adjusted to } \\
\text { help electrostatic } \\
\text { self-assembly method }\end{array}$ & [78] \\
\hline 10 & $\begin{array}{l}\text { Biomedical field: drug } \\
\text { carrier for near } \\
\text { infraredlight-responsive } \\
\text { controlled drug release }\end{array}$ & $\begin{array}{l}\text { Capped noncovalent } \\
\text { binding }\end{array}$ & $\begin{array}{l}\text { Biocompatible, biofriendly, } \\
\text { efficient killing efficacy } \\
\text { towards cancer cells }\end{array}$ & $\begin{array}{l}\text { NIR light is needed to } \\
\text { control the drug } \\
\text { release from } \\
\text { mesopores to nucleus }\end{array}$ & [82] \\
\hline
\end{tabular}


Table 3. Cont.

\begin{tabular}{|c|c|c|c|c|c|}
\hline No & $\begin{array}{l}\text { Applications of } \\
\text { Graphene/Silica } \\
\text { Composites }\end{array}$ & Method & Advantages & Challenge & Ref. \\
\hline 11 & $\begin{array}{l}\text { Biomedical field: } \\
\text { fluorescent imaging of } \\
\text { tumor cells } \\
\text { and drug delivery }\end{array}$ & Coating & $\begin{array}{l}\text { enables simultaneous } \\
\text { drug release, fluorescent } \\
\text { monitoring }\end{array}$ & $\begin{array}{l}\text { Metal ion can quench the } \\
\text { intensity } \\
\text { of the N-GQDs (N-Doped } \\
\text { graphene quantum dot) }\end{array}$ & [83] \\
\hline 12 & $\begin{array}{c}\text { Biomedical field: imaging } \\
\text { and Chemo- Photothermal } \\
\text { Synergistic } \\
\text { Therapy Against Tumor }\end{array}$ & Coating Core-Shell & $\begin{array}{l}\text { Biocompatibility, provide } \\
\text { a basis for the early } \\
\text { diagnosis and treatment of } \\
\text { tumor }\end{array}$ & $\begin{array}{l}\text { Laser radiation are needed } \\
\text { to produce a more effective } \\
\text { tumor killed }\end{array}$ & [84] \\
\hline 13 & $\begin{array}{l}\text { Biomedical field: Chemo- } \\
\text { Photothermal Therapy }\end{array}$ & Coating & $\begin{array}{l}\text { Good biocompatibility, } \\
\text { dispersibility, excellent } \\
\text { photothermalproperty, } \\
\text { remarkable tumor cell } \\
\text { killing efficiency, } \\
\text { specificity to target } \\
\text { tumor cells }\end{array}$ & $\begin{array}{l}\text { Fluoroscopy results differ in } \\
\text { certain body parts due to } \\
\text { organ efficiency }\end{array}$ & [85] \\
\hline 14 & $\begin{array}{l}\text { Catalyst: electrocatalysts } \\
\text { for methanol } \\
\text { oxidation reaction }\end{array}$ & Hydrothermal method & $\begin{array}{l}\text { Improve the } \\
\text { electrocatalytic } \\
\text { performance, long-time } \\
\text { endurance and } \\
\text { superior durability. }\end{array}$ & & [86] \\
\hline 15 & $\begin{array}{l}\text { Catalyst: photocatalytic of } \\
\text { organic dyes, gallic acid }\end{array}$ & Hydrothermal method & $\begin{array}{c}\text { Enhanced photocatalytic } \\
\text { activity for } \\
\text { organic dyes and gallic } \\
\text { acid, improved the } \\
\text { hydrogen evolution } \\
\text { process }\end{array}$ & & [88] \\
\hline 16 & $\begin{array}{l}\text { Catalyst: for Oxidation } \\
\text { and Reduction } \\
\text { Reactions }\end{array}$ & $\begin{array}{l}\text { Deposition- } \\
\text { precipitation } \\
\text { method. }\end{array}$ & $\begin{array}{l}\text { High catalytic activity } \\
\text { and excellent } \\
\text { high-temperature stability }\end{array}$ & $\begin{array}{l}\text { Nanosize } \\
\text { catalyst can agglomerate } \\
\text { and sinter very easily } \\
\text { during high } \\
\text { temperature calcination }\end{array}$ & [89] \\
\hline
\end{tabular}

Table 4. Properties of graphene, silica and graphene/silica composites and its potential applica-ions.

\begin{tabular}{|c|c|c|c|c|c|}
\hline No & Properties of Graphene & Properties of Silica & $\begin{array}{c}\text { Properties of } \\
\text { Graphene/Silica Composites }\end{array}$ & Potential Applications & Ref. \\
\hline 1 & $\begin{array}{l}\text { Graphene and its derivatives } \\
\text { exhibit high specific surface } \\
\text { area, however, graphene } \\
\text { oxide will be easily } \\
\text { agglomerated in the aqueous } \\
\text { solution and } \\
\text { re-stack between layers }\end{array}$ & $\begin{array}{l}\mathrm{SiO}_{2} \text { is a non-toxic and } \\
\text { chemically stable material } \\
\text { which not only easily } \\
\text { overcomes the aggregation } \\
\text { problem of GO but also } \\
\text { improves the specific surface } \\
\text { area and } \\
\text { adsorption properties }\end{array}$ & $\begin{array}{l}\text { The combination of graphene } \\
\text { and silica nanoparticles } \\
\text { enhance the specific surface } \\
\text { area, prevent restacking of } \\
\text { graphene sheet and produce } \\
\text { an excellent } \\
\text { adsorption capacity }\end{array}$ & $\begin{array}{l}\text { Environment and } \\
\text { adsorption material }\end{array}$ & [65-68] \\
\hline 2 & $\begin{array}{l}\text { Graphene-based materials } \\
\text { have excellent } \\
\text { chemical and physical } \\
\text { stability and high electrical } \\
\text { conductivity, however, } \\
\text { graphene sheets are easy } \\
\text { to restack }\end{array}$ & $\begin{array}{l}\mathrm{SiO}_{2} \text { particles could be } \\
\text { inserted into the space } \\
\text { between graphene sheets to } \\
\text { produce a rigid support for } \\
\text { flexible graphene sheets to } \\
\text { prevent the } \pi-\pi \text { stacking of } \\
\text { graphene sheets }\end{array}$ & $\begin{array}{l}\text { Ultrahigh specific surface } \\
\text { area, hierarchical porous } \\
\text { structure, high capacitance } \\
\text { and long lifetime }\end{array}$ & Energy storage & {$[74,77]$} \\
\hline
\end{tabular}


Table 4. Cont.

\begin{tabular}{|c|c|c|c|c|c|}
\hline No & Properties of Graphene & Properties of Silica & $\begin{array}{c}\text { Properties of } \\
\text { Graphene/Silica Composites }\end{array}$ & Potential Applications & Ref. \\
\hline 3 & $\begin{array}{l}\text { Graphene, especially } \\
\text { graphene oxide (GO), has } \\
\text { good water solubility, low } \\
\text { toxicity, good } \\
\text { biocompatibility, and easy } \\
\text { surface modification }\end{array}$ & $\begin{array}{l}\text { Silica has a high surface area, } \\
\text { good biocompatibility, } \\
\text { encapsulation capability in } \\
\text { hydrophilic and hydrophobic } \\
\text { molecules, tunable } \\
\text { morphology, and } \\
\text { scalable synthetic } \\
\text { availability }\end{array}$ & $\begin{array}{l}\text { The combination of graphene } \\
\text { and silica nanoparticles } \\
\text { exhibit excellent synergistic } \\
\text { properties include high } \\
\text { surface area, excellent } \\
\text { biocompatibility, tunable } \\
\text { morphology and low toxicity } \\
\text { as biomedical } \\
\text { composite materials }\end{array}$ & $\begin{array}{l}\text { Biomedical application } \\
\text { includes drug delivery } \\
\text { system, imaging } \\
\text { and therapy }\end{array}$ & {$[84,85]$} \\
\hline 4 & $\begin{array}{l}\text { Graphene shows strong } \\
\text { catalytic activity in } \\
\text { photocatalysis and } \\
\text { electrocatalysis, owing to its } \\
\text { large surface area, has } \\
\text { excellent conductivity } \\
\text { for electron } \\
\text { capture and transport }\end{array}$ & $\begin{array}{l}\text { Silica has large surface area, } \\
\text { regular pore size, thermal and } \\
\text { chemical stability, and } \\
\text { variable chemical functional } \\
\text { groups. Silica can prevent the } \\
\text { agglomeration of graphene, } \\
\text { and enhance the } \\
\text { electrocatalytic performance } \\
\text { of graphene }\end{array}$ & $\begin{array}{l}\text { The combination of graphene } \\
\text { and silica nanoparticles } \\
\text { integrates the advantages of } \\
\text { the two components and } \\
\text { shows remarkable } \\
\text { application prospects in } \\
\text { improving the } \\
\text { catalytic performance }\end{array}$ & Catalysis & {$[86,88]$} \\
\hline
\end{tabular}

\section{Conclusions and Future Prospects}

Various advances in synthesis methods and applications related to silica, graphene, and graphene/silica hybrid composites have been reviewed in this paper. Graphene and silica have become interesting materials for use in various fields because of their special properties. Graphene and its derivatives have properties such as a large surface area, high electrical conductivity, high thermal conductivity, high mechanical strength, great optical transmittance, high modulus of elasticity, and high electron intrinsic mobility. Silica has a wide application based on its various properties such as low density, tendency to produce the strength and hardness of ceramic materials, high porous, ultra-lightweight, biocompatibility, nanostructured properties, high specific surface area, and gas adsorption capacity due to the presence of its micro and mesopores. The several major findings for this review are (1) the current progress of strategy for synthesis graphene/silica was described with their advantages and potential applications; (2) The combination of graphene with silica in graphene/silica hybrid composite can avoid performance degradation of materials caused by agglomeration of graphene and greatly increasing specific surface area and biocompatibility. On the other hand, graphene can provide excellent mechanical properties and a high electrical and thermal conductivity. (3) The combination of graphene and silica in graphene/silica hybrid composites can form a synergistic effect to produce excellent properties. These excellent properties of graphene/silica contribute to spacious application prospects in many fields such as energy storage, catalysts, adsorbent, and biomedicine.

One of the challenges of silica/graphene-based composites is the difficulty of maximizing electrical conductivity, thermal conductivity, and electromagnetic shielding together because of their high surface areas and chemical stability that tend to resist losses. The development of new fabrication methods need to be carried out by taking into account the optimization of components and the interactions between the components graphene and silica, as well as the structure and property relationships, in order to efficiently produce properties suitable for the desired application. In this way, $\mathrm{SiO}_{2}$ /graphene composites can produce extraordinary properties that can open new technological opportunities in various fields.

Author Contributions: Conceptualization, M.H.; wrote the paper, M.H., N.N., A.N., A.B.P., E.F., E.S. and F.F.; writing-review and editing, M.H.; supervision, M.H. and A.R.; project administration, M.H.; funding acquisition, M.H. All authors have read and agreed to the published version of the manuscript.

Funding: This research was funded by National Research and Innovation Agency (BRIN), grant number 26/A/DT/2021. 
Conflicts of Interest: The authors declare no conflict of interest.

\section{References}

1. Komarneni, S. Nanocornposites. J. Mater. Chem. 1992, 2, 1219-1230. [CrossRef]

2. Thostenson, E.; Li, C.; Chou, T. Nanocomposites in context. Compos. Sci. Technol. 2005, 65, 491-516. [CrossRef]

3. Bogue, R. Nanocomposites: A review of technology and applications. Assem. Autom. 2011, 31, 106-112. [CrossRef]

4. Sonawane, G.H.; Patil, S.P.; Sonawane, S.H. Nanocomposites and Its Applications. In Applications of Nanomaterials; Elsevier Ltd.: Amsterdam, The Netherlands, 2018; pp. 1-22. [CrossRef]

5. Geim, A.K.; Novoselov, K.S. The rise of graphene. Nanosci. Technol A Collect. Rev. Nat. J. 2009, 11-19.

6. Handayani, M.; Sulistiyono, E.; Rokhmanto, F.; Darsono, N.; Fransisca, P.L.; Erryani, A.; Wardono, J.T. Fabrication of Graphene Oxide/Calcium Carbonate/Chitosan Nanocomposite Film with Enhanced Mechanical Properties. IOP Conf. Series: Mater. Sci. Eng. 2019, 578, 12073. [CrossRef]

7. Alvial-Palavicino, C.; Konrad, K. The rise of graphene expectations: Anticipatory practices in emergent nanotechnologies. Futures 2019, 109, 192-202. [CrossRef]

8. Latiff, N.M.; Fu, X.; Mohamed, D.K.; Veksha, A.; Handayani, M.; Lisak, G. Carbon based copper(II) phthalocyanine catalysts for electrochemical $\mathrm{CO}_{2}$ reduction: Effect of carbon support on electrocatalytic activity. Carbon 2020, 168, 245-253. [CrossRef]

9. Krisnandi, Y.K.; Abdullah, I.; Prabawanta, I.B.G.; Handayani, M. In-situ hydrothermal synthesis of nickel nanoparticle/reduced graphene oxides as catalyst on $\mathrm{CO}_{2}$ methanation. In AIP Conference Proceedings; AIP Publishing LLC: Melville, NY, USA, 2020; Volume 2242, p. 40046. [CrossRef]

10. Abergel, D.; Apalkov, V.; Berashevich, J.; Ziegler, K.; Chakraborty, T. Properties of graphene: A theoretical perspective. Adv. Phys. 2010, 59, 261-482. [CrossRef]

11. Tsang, A.C.H.; Huang, H.; Xuan, J.; Wang, H.; Leung, D. Graphene materials in green energy applications: Recent development and future perspective. Renew. Sustain. Energy Rev. 2020, 120, 109656. [CrossRef]

12. Zhu, Y.; Murali, S.; Cai, W.; Li, X.; Suk, J.W.; Potts, J.R.; Ruoff, R.S. Graphene-based Materials: Graphene and Graphene Oxide: Synthesis, Properties, and Applications (Adv. Mater. 35/2010). Adv. Mater. 2010, 22, 3906-3924. [CrossRef] [PubMed]

13. Papageorgiou, D.G.; Kinloch, I.A.; Young, R.J. Mechanical properties of graphene and graphene-based nanocomposites. Prog. Mater. Sci. 2017, 90, 75-127. [CrossRef]

14. Soldano, C.; Mahmood, A.; Dujardin, E. Production, properties and potential of graphene. Carbon 2010, 48, 2127-2150. [CrossRef]

15. Zainal, N.S.; Mohamad, Z.; Mustapa, M.S.; Badarulzaman, N.A.; Zulkifli, A.Z.; Bhd, S.A.N.S.S. The Ability of Crystalline and Amorphous Silica from Rice Husk Ash to Perform Quality Hardness for Ceramic Water Filtration Membrane. Int. J. Integr. Eng. 2019, 11, 229-235. [CrossRef]

16. Mulyati, S.; Muchtar, S.; Yusuf, M.; Arahman, N.; Sofyana, S.; Rosnelly, C.M.; Fathanah, U.; Takagi, R.; Matsuyama, H.; Shamsuddin, N.; et al. Production of High Flux Poly(Ether Sulfone) Membrane Using Silica Additive Extracted from Natural Resource. Membranes 2020, 10, 17. [CrossRef]

17. Sharma, J.; Polizos, G. Hollow Silica Particles: Recent Progress and Future Perspectives. Nanomaterials 2020, 10, 1599. [CrossRef]

18. Zulfiqar, U.; Subhani, T.; Husain, S.W. Synthesis and characterization of silica nanoparticles from clay. J. Asian Ceram. Soc. 2016, 4, 91-96. [CrossRef]

19. Chen, J.-J.; Li, H.-J.; Zhou, X.-H.; Li, E.-Z.; Wang, Y.; Guo, Y.-L.; Feng, Z.-S. Efficient synthesis of hollow silica microspheres useful for porous silica ceramics. Ceram. Int. 2017, 43, 13907-13912. [CrossRef]

20. Abbas, N.; Khalid, H.R.; Ban, G.; Kim, H.T.; Lee, H. Silica aerogel derived from rice husk: An aggregate replacer for lightweight and thermally insulating cement-based composites. Constr. Build. Mater. 2019, 195, 312-322. [CrossRef]

21. Sdiri, A.; Higashi, T.; Bouaziz, S.; Benzina, M. Synthesis and characterization of silica gel from siliceous sands of southern Tunisia. Arab. J. Chem. 2014, 7, 486-493. [CrossRef]

22. Ismail, A.; Saputri, L.N.M.Z.; Dwiatmoko, A.A.; Susanto, B.H.; Nasikin, M. A facile approach to synthesis of silica nanoparticles from silica sand and their application as superhydrophobic material. J. Asian Ceram. Soc. 2021, 9, 665-672. [CrossRef]

23. Qian, H.; Li, W.; Wang, X.; Xie, F.; Li, W.; Qu, Q. Simultaneous growth of graphene/mesoporous silica composites using liquid precursor for HPLC separations. Appl. Surf. Sci. 2021, 537, 148101. [CrossRef]

24. Ma, M.; Li, H.; Xiong, Y.; Dong, F. Rational design, synthesis, and application of silica/graphene-based nanocomposite: A review. Mater. Des. 2021, 198, 109367. [CrossRef]

25. Azat, S.; Sartova, Z.; Bekseitova, K.; Askaruly, K. Extraction of high-purity silica from rice husk via hydrochloric acid leaching treatment. Turk. J. Chem. 2019, 43, 1258-1269. [CrossRef]

26. Zhu, Y.; He, Y.; Li, Z.; Zhang, J.; Shen, T.; Chen, Y.; Yang, D.-Q.; Sacher, E.; Jifan, Z. Synthesis of amorphous $\mathrm{SiO}_{2}$ nanowires by one-step low temperature hydrothermal process. Mater. Res. Express 2019, 6, 115202. [CrossRef]

27. Meléndez-Ortiz, H.I.; Mercado-Silva, A.; García-Cerda, L.A.; Castruita, G.; Perera-Mercado, Y.A. Hydrothermal Synthesis of Mesoporous Silica MCM-41 Using Commercial Sodium Silicate. J. Mex. Chem. Soc. 2017, 57, 73-79. [CrossRef]

28. Park, J.; Gu, Y.; Park, S.; Hwang, E.; Sang, B.-I.; Chun, J.; Lee, J. Two-Stage Continuous Process for the Extraction of Silica from Rice Husk Using Attrition Ball Milling and Alkaline Leaching Methods. Sustainability 2021, 13, 7350. [CrossRef] 
29. Sulistiyono, E.; Handayani, M.; Prasetyo, A.B.; Irawan, J.; Febriana, E.; Firdiyono, F.; Yustanti, E.; Sembiring, S.N.; Nugroho, F.; Muslih, E.Y. Implementation of sulfuric acid leaching for aluminum and iron removal for improvement of low-grade silica from quartz sand of Sukabumi, Indonesia. East. Eur. J. Enterp. Technol. 2021, 3, 32-40. [CrossRef]

30. Febriana, E.; Manurung, U.A.B.; Prasetyo, A.B.; Handayani, M.; Muslih, E.Y.; Nugroho, F.; Sulistiyono, E.; Firdiyono, F. Dissolution of quartz sand in sodium hydroxide solution for producing amorphous precipitated silica. IOP Conf. Series: Mater. Sci. Eng. 2020, 858, 012047. [CrossRef]

31. Gao, F.; Peng, Z.; Fu, X. One-Step Synthesis and Characterization of Silica Nano-/Submicron Spheres by Catalyst-Assisted Pyrolysis of a Preceramic Polymer. J. Nanomater. 2013, 2013, 5. [CrossRef]

32. Cho, K.; Chang, H.; Kil, D.S.; Park, J.; Jang, H.D.; Sohn, H.Y. Mechanisms of the Formation of Silica Particles from Precursors with Different Volatilities by Flame Spray Pyrolysis. Aerosol Sci. Technol. 2009, 43, 911-920. [CrossRef]

33. Avouris, P.; Dimitrakopoulos, C. Graphene: Synthesis and applications. Mater. Today 2012, 15, 86-97. [CrossRef]

34. Edwards, R.S.; Coleman, K.S. Graphene synthesis: Relationship to applications. Nanoscale 2013, 5, 38-51. [CrossRef]

35. Zhang, Z.; Fraser, A.; Ye, S.; Merle, G.; Barralet, J.E. Top-down bottom-up graphene synthesis. Nano Futur. 2019,3 , 042003. [CrossRef]

36. Potts, J.R.; Dreyer, D.R.; Bielawski, C.W.; Ruoff, R.S. Graphene-based polymer nanocomposites. Polymers 2011, 52, 5-25. [CrossRef]

37. Cooper, D.R.; D'Anjou, B.; Ghattamaneni, N.; Harack, B.; Hilke, M.; Horth, A.; Majlis, N.; Massicotte, M.; Vandsburger, L.; Whiteway, E.; et al. Experimental Review of Graphene. ISRN Condens. Matter Phys. 2012, 2012, 501686. [CrossRef]

38. Eswaraiah, V.; Aravind, S.S.J.; Ramaprabhu, S. Top down method for synthesis of highly conducting graphene by exfoliation of graphite oxide using focused solar radiation. J. Mater. Chem. 2011, 21, 6800-6803. [CrossRef]

39. Handayani, M.; Kepakisan, K.A.A.; Anshori, I.; Darsono, N.; Thaha, Y.N. Graphene oxide based nanocomposite modified screen printed carbon electrode for qualitative cefixime detection. Proc. Int. Semin. Metall. Mater. Accel. Res. Innov. Metall. Mater. Incl. Sustain. Ind. 2021, 2382, 40005. [CrossRef]

40. Kim, H.; Abdala, A.A.; MacOsko, C.W. Graphene/polymer nanocomposites. Macromolecules 2010, 43, 6515-6530. [CrossRef]

41. Febriana, E.; Handayani, M.; Susilo, D.N.A.; Yahya, M.S.; Ganta, M.; Sunnardianto, G.K. A simple approach of synthesis of graphene oxide from pure graphite: Time stirring duration variation. Proc. Int. Semin. Metall. Mater. Accel. Res. Innov. Metall. Mater. Incl. Sustain. Ind. 2021, 2382, 40006. [CrossRef]

42. Handayani, M.; Ganta, M.; Susilo, D.N.A.; Yahya, M.S.; Sunnardianto, G.K.; Darsono, N.; Sulistiyono, E.; Setiawan, I.; Lestari, F.P.; Erryani, A. Synthesis of graphene oxide from used electrode graphite with controlled oxidation process. IOP Conf. Ser. Mater. Sci. Eng. 2019, 541, 12032. [CrossRef]

43. Abbas, A.; Eng, X.E.; Ee, N.; Saleem, F.; Wu, D.; Chen, W.; Handayani, M.; Tabish, T.A.; Wai, N.; Lim, T.M. Development of reduced graphene oxide from biowaste as an electrode material for vanadium redox flow battery. J. Energy Storage 2021, 41, 102848. [CrossRef]

44. Chen, H.; He, G.; Zhu, J.; Bei, F.; Sun, X.; Wang, X. Synthesis and characterization of graphene paper with controllable properties via chemical reduction. J. Mater. Chem. 2011, 21, 14631-14638. [CrossRef]

45. Zhang, X.; Li, K.; Li, H.; Lu, J.; Fu, Q.; Chu, Y. Graphene nanosheets synthesis via chemical reduction of graphene oxide using sodium acetate trihydrate solution. Synth. Met. 2014, 193, 132-138. [CrossRef]

46. Toh, S.Y.; Loh, K.S.; Kamarudin, S.K.; Daud, W.R.W. Graphene production via electrochemical reduction of graphene oxide: Synthesis and characterisation. Chem. Eng. J. 2014, 251, 422-434. [CrossRef]

47. Liu, J.; Yang, H.; Zhen, S.G.; Poh, C.K.; Chaurasia, A.; Luo, J.; Wu, X.; Yeow, E.K.L.; Sahoo, N.G.; Lin, J.; et al. A Green Approach to the Synthesis of High-Quality Graphene Oxide Flakes via Electrochemical Exfoliation of Pencil Core. RSC Adv. 2013, 207890, 8669-8679. [CrossRef]

48. Parvez, K.; Li, R.; Puniredd, S.R.; Hernandez, Y.; Hinkel, F.; Wang, S.; Feng, X.; Mullen, K. Electrochemically exfoliated graphene as solution-processable, highly conductive electrodes for organic electronics. ACS Nano 2013, 7, 3598-3606. [CrossRef]

49. Wu, H.; Zhao, W.; Hu, H.; Chen, G. One-step in situ ball milling synthesis of polymer-functionalized graphene nanocomposites. J. Mater. Chem. 2011, 21, 8626-8632. [CrossRef]

50. Mondal, O.; Mitra, S.; Pal, M.; Datta, A.; Dhara, S.; Chakravorty, D. Reduced graphene oxide synthesis by high energy ball milling. Mater. Chem. Phys. 2015, 161, 123-129. [CrossRef]

51. Lin, C.; Yang, L.; Ouyang, L.; Liu, J.; Wang, H.; Zhu, M. A new method for few-layer graphene preparation via plasma-assisted ball milling. J. Alloys Compd. 2017, 728, 578-584. [CrossRef]

52. Li, X.; Magnuson, C.W.; Venugopal, A.; Tromp, R.M.; Hannon, J.B.; Vogel, E.M.; Colombo, L.; Ruoff, R.S. Large-Area Graphene Single Crystals Grown by Low-Pressure Chemical Vapor Deposition of Methane on Copper. J. Am. Chem. Soc. 2011, 133, 2816-2819. [CrossRef]

53. Li, X.; Magnuson, C.W.; Venugopal, A.; An, J.; Suk, J.W.; Han, B.; Borysiak, M.; Cai, W.; Velamakanni, A.; Zhu, Y.; et al. Graphene Films with Large Domain Size by a Two-Step Chemical Vapor Deposition Process. Nano Lett. 2010, 10, 4328-4334. [CrossRef]

54. Liu, H.; Liu, Y. Controlled Chemical Synthesis in CVD Graphene. Phys. Sci. Rev. 2017, 2, 1-28. [CrossRef]

55. Wu, Y.; Wang, B.; Ma, Y.; Huang, Y.; Li, N.; Zhang, F.; Chen, Y. Efficient and large-scale synthesis of few-layered graphene using an arc-discharge method and conductivity studies of the resulting films. Nano Res. 2010, 3, 661-669. [CrossRef]

56. Kim, S.; Song, Y.; Wright, J.; Heller, M.J. Graphene bi- and trilayers produced by a novel aqueous arc discharge process. Carbon 2016, 102, 339-345. [CrossRef] 
57. Wu, Z.-S.; Ren, W.; Gao, L.; Zhao, J.; Chen, Z.; Liu, B.; Tang, D.; Yu, B.; Jiang, C.; Cheng, H.-M. Synthesis of Graphene Sheets with High Electrical Conductivity and Good Thermal Stability by Hydrogen Arc Discharge Exfoliation. ACS Nano 2009, 3, $411-417$. [CrossRef] [PubMed]

58. Yi, G.; Xing, B.; Zeng, H.; Wang, X.; Zhang, C.; Cao, J.; Chen, L. One-Step Synthesis of Hierarchical Micro-Mesoporous $\mathrm{SiO}_{2}$ /Reduced Graphene Oxide Nanocomposites for Adsorption of Aqueous Cr(VI). J. Nanomater. 2017, 2017, 6286549. [CrossRef]

59. Oh, B.; Oh, J.-S.; Lee, E.-J.; Han, C.-M. Synthesis of uniformly dispersed silica/graphene oxide composite hydrogel using acid/base combinatorial catalysts system. Mater. Today Commun. 2021, 26, 101841. [CrossRef]

60. Haeri, S.; Asghari, M.; Ramezanzadeh, B. Enhancement of the mechanical properties of an epoxy composite through inclusion of graphene oxide nanosheets functionalized with silica nanoparticles through one and two steps sol-gel routes. Prog. Org. Coatings 2017, 111, 1-12. [CrossRef]

61. Wang, M.; Ma, L.; Li, B.; Zhang, W.; Zheng, H.; Wu, G.; Huang, Y.; Song, G. One-step generation of silica particles onto graphene oxide sheets for superior mechanical properties of epoxy composite and scale application. Compos. Commun. 2020, $22,100514$. [CrossRef]

62. Zhang, W.L.; Choi, H.J. Silica-Graphene Oxide Hybrid Composite Particles and Their Electroresponsive Characteristics. Langmuir 2012, 28, 7055-7062. [CrossRef] [PubMed]

63. Chen, L.; Chai, S.; Liu, K.; Ning, N.; Gao, J.; Liu, Q.; Chen, F.; Fu, Q. Enhanced Epoxy/Silica Composites Mechanical Properties by Introducing Graphene Oxide to the Interface. ACS Appl. Mater. Interfaces 2012, 4, 4398-4404. [CrossRef]

64. Ye, W.; Zhang, L.; Li, C. Facile fabrication of silica-polymer-graphene collaborative nanostructure-based hybrid materials with high conductivity and robust mechanical performance. RSC Adv. 2015, 5, 25450-25456. [CrossRef]

65. Liu, P.; Liang, Q.; Luo, H.; Fang, W.; Geng, J. Synthesis of nano-scale zero-valent iron-reduced graphene oxide-silica nanocomposites for the efficient removal of arsenic from aqueous solutions. Environ. Sci. Pollut. Res. 2019, 26, 33507-33516. [CrossRef] [PubMed]

66. Wang, X.; Pei, Y.; Lu, M.; Lu, X.; Du, X. Highly efficient adsorption of heavy metals from wastewaters by graphene oxide-ordered mesoporous silica materials. J. Mater. Sci. 2015, 50, 2113-2121. [CrossRef]

67. Wang, X.; Wang, H.; Lu, M.; Teng, R.; Du, X. Facile synthesis of phenyl-modified magnetic graphene/mesoporous silica with hierarchical bridge-pore structure for efficient adsorption of pesticides. Mater. Chem. Phys. 2017, 198, 393-400. [CrossRef]

68. Liu, F.; Wu, Z.; Wang, D.; Yu, J.; Jiang, X.; Chen, X. Magnetic porous silica-graphene oxide hybrid composite as a potential adsorbent for aqueous removal of $\mathrm{p}$-nitrophenol. Colloids Surfaces A: Physicochem. Eng. Asp. 2016, 490, 207-214. [CrossRef]

69. Wang, W.; Motuzas, J.; Zhao, X.S.; da Costa, J.C.D. 2D/3D amine functionalised sorbents containing graphene silica aerogel and mesoporous silica with improved $\mathrm{CO}_{2}$ sorption. Sep. Purif. Technol. 2019, 222, 381-389. [CrossRef]

70. Zhao, B.; Sun, T.; Zhou, X.; Liu, X.; Li, X.; Zhou, K.; Dong, L.; Wei, D. Three-dimensional graphene composite containing graphene- $\mathrm{SiO}_{2}$ nanoballs and its potential application in stress sensors. Nanomaterials 2019, 9, 438. [CrossRef]

71. Zhang, L.L.; Zhou, R.; Zhao, X.S. Graphene-based materials as supercapacitor electrodes. J. Mater. Chem. 2010, 20 , 5983-5992. [CrossRef]

72. Ghosh, A.; Miah, M.; Majumder, C.; Bag, S.; Chakravorty, D.; Saha, S.K. Synthesis of multilayered structure of nano-dimensional silica glass/reduced graphene oxide for advanced electrochemical applications. Nanoscale 2018, 10, 5539-5549. [CrossRef]

73. Kim, M.; Kim, H.K. Ultraviolet-enhanced photodetection in a graphene $/ \mathrm{SiO}_{2} / \mathrm{Si}$ capacitor structure with a vacuum channel. $J$. Appl. Phys. 2015, 118, 104504. [CrossRef]

74. Du, Y.; Liu, L.; Xiang, Y.; Zhang, Q. Enhanced electrochemical capacitance and oil-absorbability of N-doped graphene aerogel by using amino-functionalized silica as template and doping agent. J. Power Sources 2018, 379, 240-248. [CrossRef]

75. Lu, L.; Han, X.; Li, J.; Hua, J.; Ouyang, M. A review on the key issues for lithium-ion battery management in electric vehicles. $J$. Power Sources 2013, 226, 272-288. [CrossRef]

76. Li, H.; Lu, C. Preparation of three-dimensional graphene networks for use as anode of lithium ion batteries. Funct. Mater. Lett. 2013, 6, 2-5. [CrossRef]

77. Yin, L.-H.; Wu, M.; Li, Y.-P.; Wu, G.-L.; Wang, Y.-K.; Wang, Y. Synthesis of $\mathrm{SiO}_{2}$ @carbon-graphene hybrids as anode materials of lithium-ion batteries. New Carbon Mater. 2017, 32, 311-318. [CrossRef]

78. Wang, M.-S.; Wang, Z.-Q.; Jia, R.; Yang, Y.; Zhu, F.-Y.; Yang, Z.-L.; Huang, Y.; Li, X.; Xu, W. Facile electrostatic self-assembly of silicon/reduced graphene oxide porous composite by silica assist as high performance anode for Li-ion battery. Appl. Surf. Sci. 2018, 456, 379-389. [CrossRef]

79. Kim, J.; Kim, D.; Ryu, J.H.; Yoon, S. One pot synthesis of ordered mesoporous carbon-silica-titania with parallel alignment against graphene as advanced anode material in lithium ion batteries. J. Ind. Eng. Chem. 2019, 71, 93-98. [CrossRef]

80. Kim, K.H.; Jun, Y.-S.; Gerbec, J.A.; See, K.A.; Stucky, G.D.; Jung, H.-T. Sulfur infiltrated mesoporous graphene-silica composite as a polysulfide retaining cathode material for lithium-sulfur batteries. Carbon 2014, 69, 543-551. [CrossRef]

81. Zhao, Z.; Zheng, L.; Hu, W.; Zheng, H. Synergistic effect of silane and graphene oxide for enhancing the photoelectrochemical water oxidation performance of WO3NS arrays. Electrochim. Acta 2018, 292, 322-330. [CrossRef]

82. He, D.; Li, X.; He, X.; Wang, K.; Tang, J.; Yang, X.; He, X.; Yang, X.; Zou, Z. Noncovalent assembly of reduced graphene oxide and alkyl-grafted mesoporous silica: An effective drug carrier for near-infrared light-responsive controlled drug release. J. Mater. Chem. B 2015, 3, 5588-5594. [CrossRef] 
83. Gui, W.; Zhang, J.; Chen, X.; Yu, D.; Ma, Q. N-Doped graphene quantum dot@mesoporous silica nanoparticles modified with hyaluronic acid for fluorescent imaging of tumor cells and drug delivery. Microchim. Acta 2018, 185, 66. [CrossRef] [PubMed]

84. Song, Y.-Y.; Li, C.; Yang, X.-Q.; An, J.; Cheng, K.; Xuan, Y.; Shi, X.-M.; Gao, M.-J.; Song, X.-L.; Zhao, Y.-D.; et al. Graphene oxide coating core-shell silver sulfide@mesoporous silica for active targeted dual-mode imaging and chemo-photothermal synergistic therapy against tumors. J. Mater. Chem. B 2018, 6, 4808-4820. [CrossRef] [PubMed]

85. Shao, L.; Zhang, R.; Lu, J.; Zhao, C.; Deng, X.; Wu, Y. Mesoporous Silica Coated Polydopamine Functionalized Reduced Graphene Oxide for Synergistic Targeted Chemo-Photothermal Therapy. ACS Appl. Mater. Interfaces 2017, 9, 1226-1236. [CrossRef] [PubMed]

86. Yang, F.; Zhang, B.; Dong, S.; Tang, Y.; Hou, L.; Chen, Z.; Li, Z.; Yang, W.; Xu, C.; Wang, M.; et al. Silica nanosphere supported palladium nanoparticles encapsulated with graphene: High-performance electrocatalysts for methanol oxidation reaction. Appl. Surf. Sci. 2018, 452, 11-18. [CrossRef]

87. Nguyen, D.C.T.; Woo, J.-H.; Cho, K.Y.; Jung, C.-H.; Oh, W.-C. Highly efficient visible light driven photocatalytic activities of the LaCuS2-graphene composite-decorated ordered mesoporous silica. Sep. Purif. Technol. 2018, 205, 11-21. [CrossRef]

88. Oh, W.-C.; Nguyen, D.C.T.; Areerob, Y. Novel cadmium oxide-graphene nanocomposite grown on mesoporous silica for simultaneous photocatalytic H2-evolution. Chemosphere 2020, 239, 124825. [CrossRef] [PubMed]

89. Shang, L.; Bian, T.; Zhang, B.; Zhang, D.; Wu, L.-Z.; Tung, C.-H.; Yin, Y.; Zhang, T. Graphene-Supported Ultrafine Metal Nanoparticles Encapsulated by Mesoporous Silica: Robust Catalysts for Oxidation and Reduction Reactions. Angew Chem. 2014, 126, 254-258. [CrossRef]

90. Sarkar, C.; Pendem, S.; Shrotri, A.; Dao, D.Q.; Mai, P.P.T.; Ngoc, T.N.; Chandaka, D.R.; Rao, T.V.; Trinh, Q.T.; Sherburne, M.P.; et al. Interface Engineering of Graphene-Supported Cu Nanoparticles Encapsulated by Mesoporous Silica for Size-Dependent Catalytic Oxidative Coupling of Aromatic Amines. ACS Appl. Mater. Interfaces 2019, 11, 11722-11735. [CrossRef] 